2015-04-01

\title{
Endangered Quino checkerspot butterfly and climate change: Short-term success but long-term vulnerability?
}

\section{Parmesan, C}

http://hdl.handle.net/10026.1/10112

\subsection{7/s10841-014-9743-4 \\ Journal of Insect Conservation}

All content in PEARL is protected by copyright law. Author manuscripts are made available in accordance with publisher policies. Please cite only the published version using the details provided on the item record or document. In the absence of an open licence (e.g. Creative Commons), permissions for further reuse of content should be sought from the publisher or author. 


\title{
Endangered Quino checkerspot butterfly and climate change: Short-term success but long-term vulnerability?
}

\author{
Camille Parmesan • Alison Williams-Anderson • \\ Matthew Moskwik • Alexander S. Mikheyev • \\ Michael C. Singer
}

Received: 21 July 2014/ Accepted: 26 November 2014

(c) Springer International Publishing Switzerland 2014

\begin{abstract}
The butterfly Euphydryas editha is known to be vulnerable to climate events that exacerbate natural phenological asynchrony between insect and hosts. In prior work, populations of $E$. editha have been more persistent at high latitudes and high elevations than in the south and at low elevations, consistent with response to observed warming climate. However, poleward range shifts by the endangered subspecies E. e. quino are blocked by urbanization and range shifts to higher elevation may require host shifts. Prior studies were inconclusive as to whether elevational and host shifts were already occurring. Here, we re-evaluate this scenario with new evidence from
\end{abstract}

Electronic supplementary material The online version of this article (doi:10.1007/s10841-014-9743-4) contains supplementary material, which is available to authorized users.

\section{Parmesan}

Marine Institute, Plymouth University, Plymouth PL4 8AA, UK

C. Parmesan $(\square)$

Department of Geology and Environmental Science Institute, University of Texas at Austin, Austin, TX 78712, USA

e-mail: parmesan@uts.cc.utexas.edu

\section{A. Williams-Anderson}

Carlsbad Fish and Wildlife Office, 2177 Salk Avenue, Suite 250,

Carlsbad, CA 92008, USA

M. Moskwik

Department of Integrative Biology, University of Texas at Austin, Austin, TX 78712, USA

\section{A. S. Mikheyev}

Okinawa Institute of Science and Technology, Onna-son, Okinawa 904-0495, Japan

M. C. Singer

School of Biological Sciences, Plymouth University, Plymouth PL4 8AA, UK molecular genetics, host-choice behaviour and field recording of butterfly distribution. We found a statistically significant upward shift in population distribution since 2009. Insects in the expanding region were neither genomic outliers within Quino nor specifically adapted to their principal local host genus, Collinsia. These diverse data collectively support the hypothesis that an elevational range expansion is already in progress, accompanied and facilitated by a shift of principal host from Plantago to Collinsia. Quino appears resilient to warming climate. However, projections indicate that most or all of Quino's current range in the USA, including the new high elevation expansion, will become uninhabitable. Our most frequent projected future range (circa 2050) is c. $400 \mathrm{~km}$ northward from current populations, hence conservation of Quino may eventually require assisted colonization. For now, Critical Habitat (sensu Endangered Species Act) has been designated at sites around the new upper elevational limit that were not known to be occupied. Designating Critical Habitat outside the historic range is a pioneering response to climate change. This politically challenging, non-traditional, climate change-oriented conservation effort exemplifies flexible thinking needed for species vulnerable to climate change.

Keywords Assisted colonization - Climate change . Global warming · Critical Habitat · Endangered Species Act $\cdot$ Euphydryas editha quino

\section{Introduction}

Anthropogenic climate change has altered the distributions of species around the world (Parmesan and Yohe 2003; Root et al. 2003; Parmesan 2006; Rosenzweig et al. 2008; 
Chen et al. 2011a; Poloczanska et al. 2013; IPCC 2014). Species that are already under stress from other human activities are likely more vulnerable to global warming due to decreased resistance and resilience (Parmesan and Galbraith 2004; Parmesan et al. 2013). In these circumstances, the conservation community is increasingly concerned with how to manage biodiversity. Global warming is fundamentally different from other anthropogenic influences in that it is not driven by local activities, rendering direct mitigation at the local level difficult. Nonetheless, a wide diversity of approaches for indirect local mitigation has already been advocated (reviewed by Mawdsley et al. 2009; Lawler 2009; Heller and Zavaleta 2009; Evans et al. in press).

Even without climate change, it is becoming increasingly difficult to prevent already-endangered species from going extinct without continuous management. For example, most species listed under the United States Endangered Species Act (ESA) are currently conservation reliant; that is, they require active management in order to persist (Evans et al. in press). Anthropogenic climate change exacerbates this requirement, with 'climate-smart' recommendations all requiring more intensive management. True recovery (sensu ESA), that is, ability of a population or species to persist in the absence of active management, will become increasingly difficult.

There is emerging documentation that ecosystems that are initially less degraded by human activities are both less altered by extreme climate events (i.e. more resistant) as well as recovering more rapidly than degraded systems after climate-change induced impacts (i.e. more resilient; Hughes et al. 2007; Ling et al. 2009; Johnson et al. 2011). Therefore, although biologists can't prevent climate change, one way in which we can mitigate its effects is to foster ecosystem resistance and resilience by applying traditional conservation approaches, such as increasing habitat connectivity with renewed vigour (Heller and Zavaleta 2009; Parmesan et al. 2013). Particular cases may require addition of non-traditional approaches such as assisted colonization (Hoegh-Guldberg et al. 2008; Richardson et al. 2009; Schwartz et al. 2012) and/or genetic rescue (see Special Issue of Phil Trans Roy Soc 2013 on Genetic Rescue, specifically Gomulkiewicz and Shaw 2013; Gonzalez and Bell 2013; Kirkpatrick and Peischl 2013).

Recovery under climate change requires that we not only acknowledge and address current habitat needs, but also prepare for and anticipate changing threats and needs. The appropriate balance between traditional and novel approaches should be developed by incorporating species' climate change vulnerability assessments into recovery planning and by exercising rapid-response adaptive management (Foden et al. 2013; Glick et al. 2011; Dawson et al. 2011; Thomas et al. 2011; Evans et al. in press). Here we describe a case study demonstrating rapid, innovative management response to climate change impacts using a Federally endangered butterfly, the Quino checkerspot (Euphydryas editha quino), hereafter referred to as "Quino."

Quino checkerspot: at risk from climate change

Quino is a distinct subspecies of Euphydryas editha (Edith's checkerspot butterfly), a non-migratory species with discrete populations and metapopulations distributed across the western USA, northern Baja California (Mexico), and southern regions of British Columbia and Alberta (Canada). Currently, three sub-species of Edith's checkerspot (Quino, Bay checkerspot and Taylor's checkerspot) are Federally listed as endangered. Quino's listing is typical for the US Endangered Species Act (ESA 1973, as amended), with endangerment status derived largely from massive loss of habitat to development and agriculture across the insect's range in southern California, resulting in extirpation of $95 \%$ of known US populations by the time of listing, amid continued threat of ongoing development (USFWS 2003; Preston et al. 2012). Habitat degradation has compromised many of the existing sites where Quino is still found, throughout the subspecies' range. Degradation stems from several sources: partly from non-native invasive annuals out-competing native annual host plants (likely aided by nitrogen loading from automobile pollution), partly from a recent spate of fires, partly from continued urban development, and partly due to a warming, drying climate (USFWS 2009a).

Although the decline that led to Quino being listed as Endangered was overwhelmingly due to habitat destruction, as evidenced by the association between extinct/ extant status of populations and their proximity to humans (Preston et al. 2012), Quino is also a climate-sensitive insect likely to be vulnerable to future climate warming. The majority of evidence for this climate-sensitivity comes from other subspecies of Edith's checkerspot, but we have no reason to suspect Quino to be immune to the stresses suffered by conspecifics in other parts of the range. Both Bay checkerspot and Quino use small, ephemeral annual Plantago species as one of their principal hosts. Early work showed severe phenological asynchrony between the Bay checkerspot (E. e. bayensis) and its Plantago hosts, with more than $90 \%$ of larvae starving in April/May each year because the host senesced before the larvae were large enough to enter summer diapause (Singer 1972; Weiss et al. 1988). This phenological mismatch between insects and host existed prior to recent climate warming and is likely an adaptive response by the insects to a tradeoff 
between adult fecundity and offspring mortality (Singer and Parmesan 2010).

Whatever its evolutionary cause, the observed insect/ plant phenological mismatch renders E. editha populations feeding on annual plants vulnerable to year-to-year climatic fluctuations. Any climatic event that advances the phenology of the plants more than that of the insects increases larval mortality. The extinction of a small Bay checkerspot metapopulation in a protected habitat was ascribed to increased inter-year variability of winter/spring rainfall (McLaughlin et al. 2002) and several E. editha populations in the Sierra Nevada were extinguished in a drought when seeds of their annual host (Collinsia tinctoria) failed to germinate (Ehrlich et al. 1980).

Parmesan (1996) recorded presence and absence of $E$. editha at sites where her field censuses documented suitable habitat, ignoring degraded habitats. Within that set of suitable sites, the proportion of historically recorded $E$. editha populations persisting into the 1990s increased significantly with both increasing latitude and altitude. This northward and upward shift in the center of abundance of the species was consistent with response to the regional warming that had occurred in the previous decades (see Discussion). Within the species E. editha, we would expect populations towards the equatorial range limit, i.e. Quino, to be particularly vulnerable to future warming. This expectation has been recognized: according to a study done by The Center for Biological Diversity (2010), Quino was one of the first listed species to have the threat of climate change clearly identified in its species recovery plan (USFWS 2003).

Evaluating Quino ecological dynamics in the light of anthropogenic climate change

Quino's northernmost current distribution is south of its historical latitudinal northern range limit, but urban development in Los Angeles megalopolis currently blocks natural recolonization of formerly-occupied northern sites (USFWS 2003). This situation effectively negates any chance of a natural northward range shift in the subspecies. However, upward elevational range shifts are possible both within the traditional range and to the east. Here, we discuss the evidence that they are already occurring. We investigate recent trends in Quino's distribution using multiple approaches, including geographic analyses, genetic analyses and behavioral analyses, to determine (1) the likelihood that a true upward range expansion of Quino is occurring, and (2) the likelihood that newly discovered populations represent a shift to a novel host plant species. We combine this information with projections from species distribution models to examine the prospects for persistence of Quino into the near- and mid-term future both within its current range and in potential novel ranges. We use the results of these projections to consider various management options that might be utilized.

We update evidence on the question of whether a range shift is already under way. Prior evidence has been suggestive but difficult to evaluate. During development of the species Recovery Plan (USFWS 2003), in the early 2000s, previously undocumented Quino populations were discovered within and to the south of the community of Anza in Riverside County (Pratt et al. 2001; USFWS 2003, 2008, 2009a, b; Preston et al. 2012). Populations within this area of apparent range expansion were, on average, at higher elevations than extant Quino populations within the traditional range, while the latter were, in turn, at higher mean elevation than extinct populations in the traditional range (Preston et al. 2012, their Fig. 3a).

The principal host at the "new" sites, Collinsia concolor, belonged to a genus well-known as a host of northern California and Oregon E. editha populations (Singer 1971; Singer and McBride 2012) but not recorded as a host of Quino prior to the report by Pratt and Pierce (2008). Preston et al. (2012), summarizing data available up to 2009 , noted that the apparent upward range shift of Quino may be real or may simply represent increased searching for Quino by local lepidopterists since its listing as Endangered in 1997. They also noted that the higher mean elevation of extant, compared to extinct populations within the traditional range of Quino could be accounted for by an elevational bias in human land use.

Here, we combine behavioural data, molecular data and new field observations of Quino to tackle two questions left open in prior work:

1. Is Quino currently expanding its range to higher elevations in a manner consistent with regional climate change and not explained by patterns of human land use?

2. Is the use of Collinsia as a principal host longstanding or relatively novel for Quino?

To begin tackling these questions, we estimate the temporal and spatial patterns of colonization by analyzing dates and elevations of "First Record," with "First Record" defined as the very first observation made at each site. We then analyze molecular data to ask whether the "new" Collinsia-feeding Quino populations are genomically distinct from previously-known Quino populations feeding on Plantago and Antirrhinum and/or whether they resemble other populations of $E$. editha from southern California known to feed on Collinsia but not classified as Quino. We present data on oviposition preference and geotaxis and ask whether Collinsia-feeding Quino possess the set of evolved adaptations to Collinsia that have been documented in non-Quino E. editha adapted to this host genus. 
We summarize recent and expected future trends in regional climate, and develop a series of species distribution models aimed at giving a robust estimate of Quino's expected distribution into the near- and mid-future in light of uncertainties both in regional climate change and in species projections. Finally, we report how the Endangered Species Act is supporting non-traditional, proactive regulation and adaptive management to protect this endangered species.

\section{Methods}

\section{Distribution records}

Quino's historical distribution extended from about $200 \mathrm{~km}$ north of the USA-Mexican border to about $300 \mathrm{~km}$ south of the border, and inland only about $80 \mathrm{~km}$ from the coast. Historically, the highest density of populations was in what is now the greater San Diego area. The current latitudinal distribution of Quino has contracted slightly at both extremes. The northernmost populations have been destroyed by fire and urbanization, while the southern-most population had gone extinct by Parmesan's 1990s census (Parmesan 1996) and the next most-southern population that was recently recorded is about $50 \mathrm{~km}$ further north $(\mathrm{P}$ Opler, pers. comm.).

Data on the current status of Quino come from several sources. Historical records used in the initial listing proposal were collected by the US Fish and Wildlife Service (FWS) from museum collections and private lepidopterists' collections and recorded diaries. Current status was assessed using data from multiple sources, all of which were ultimately sent to the FWS. First, annual surveys were conducted at sentinel sites from 2001 to 2013 under the auspices of the FWS and their partners, both for routine status assessment in known populations and for the purpose of amending or updating recovery planning. Surveyors were either FWS staff or private consultants experienced in identification of Quino host plants, Quino habitat characteristics, and Quino itself in all life stages. Second, surveys were conducted as part of required environmental assessments for urban planning and development applications. These were done by experienced consultants who were required to pass a test in identification of Quino and in distinguishing it from similar species. Third, records were accepted from experienced amateur lepidopterists. There is a strong local tradition of lepidopterists exploring new areas, leading to occasional reports of Quino from sites that had not been historically recorded as Quino habitat. Some of these new records have been published in
Lepidopterological newsletters as well as the primary literature. New reports of Quino (published and unpublished) are typically verified with high-quality photographs, organized and maintained by FWS and incorporated into their GIS database. Finally, records from Baja, Mexico were obtained from Parmesan (1996), with historical records having been gathered from museum specimens and current status gathered through field censuses conducted between 1993 and 1996.

Elevational changes through time

Since we were primarily interested in documenting the dynamics of the sub-species' overall distribution, we confined our analyses of elevational range dynamics to the first record, or the 'discovery' date, for each population. Where individuals were found at explicitly different elevations within the same population, we used the elevation of the first individual found. We conducted two types of analysis to detect long-term changes in elevational distribution: (1) a correlation analysis to look for overall association between date of discovery and elevation and (2) an analysis of three time periods that differed substantially in the overall level of threat to Quino as well as Quino's protected status.

The first discovery of established Quino populations in the area of apparent range expansion was in 1998 (Pratt et al. 2001). We split our own First Records of Quino occurrence at each population into three time periods, as follows:

- 1890-1997: The historical dataset-prior to listing. Most of the low-elevation habitats had been destroyed by 1997 .

- 1998-2009: During this time period, we expect increased geographic coverage and intensity of search for new populations triggered both by listing of the species as endangered in 1997 and by Pratt et al's (2001) documentation of populations beyond historical elevational boundaries.

- 2010-2013: This time period contains the newest discoveries not previously published or included in any prior analyses. We expect diminution of the effects of increased searching on first-discoveries of longestablished populations

Within each time period, we calculated the mean elevations of First Records across the entire historic and current range of Quino. Readers interested in performing their own analyses of changes in Quino distribution over time can access the publicly-available database from USFWS. 
Modeling current and future projected distributions for Quino

Current and future climatic ranges for E. e. quino were modeled using a niche modeling approach, also known as a "species distribution model" or "SDM." We used two approaches for the SDMs: (1) using only USA sites and (2) using both USA sites and Mexican sites. The distribution within the USA that was used to calculate the climate envelope was generated from its 'current' distribution, that we defined as records of extant populations made between 1990 and 2005. Quino populations in Baja California, Mexico were also included in a second approach to calculation of currently-occupied climate space, based on sites reported as extant by Parmesan (1996), plus two sites reported to us as occupied in the current decade (P. Opler and G. Pratt, personal communications). Urban areas designated by the 2010 Census Urban Area layer (US Census Bureau 2010) were removed for the creation of the models (i.e. those areas were not used to parameterize the model of estimated climate space), but not for current or future projections (i.e. a pixel could be categorized in the output projection as "suitable" even if it had been designated as "urban").

For the SDMs based solely on USA sites, we obtained "current" climate data from PRISM Climate Group's 30 arc-second $(800 \mathrm{~m} \times 800 \mathrm{~m})$ grid for the 1971-2000 period (DiLuzio et al. 2008). This time period matches the time period of our 'current' records. We modeled the current climate space occupied by Quino and projected it onto a map to illustrate the area that could potentially have been occupied, judged from a climate perspective, in 1971-2000. To do this we used four species' distribution models: specifically a generalized linear model, generalized boosted regression model, random forest model and multivariate adaptive regression spline model. All were run in BIOMOD 1.1-7.04 (Thuiller et al. 2009). We chose four unique combinations of climate variables from among 19 commonly-used bioclimatic variables and four spatial modeling regions (i.e. backgrounds where 500 pseudoabsence points were randomly drawn). The choices for climate variables to include were made via logistic regression using a rule-based criterion that identified those variables that were most significantly associated with the observational records and pseudo-absence data. As an example, one of the rules used was that variables correlated by 0.70 or more with each other were placed in different subsets, such that the final four climate variable sets did not have variables in common with each other. This process of selecting and modeling different combinations of climate variables and pseudo-absence regions resulted in 64 model outputs, each comprising an estimate of the potential distribution of Quino, based on climate space, in the period 1971-2000.

PRISM data did not extend into Mexico. Therefore, for the SDMs derived from current occupancy of both USA and Mexican sites, we had to use a different climate dataset-WorldClim ( $\mathrm{v}$ 1.4, Hijmans et al. 2005)—to construct the models.

Future climate data were generated from 11 general circulation model and regional climate model (GCM/RCM) combinations from the North American Regional Climate Change Assessment Program (NARCAP) suite for the time period 2041-2070 under the A2 "business-as-usual" scenario (Mearns et al. 2009). GCM/RCM outputs were downscaled to 30 arc-sec $(800 \mathrm{~m} \times 800 \mathrm{~m})$ using the delta method (derived from the PRISM dataset) by Seth McGinnis at the National Center for Atmospheric Research (NCAR). Overall, this yielded 704 future projections; that is, 704 unique individual possible future scenarios for the expected distribution of Quino based solely on climate space.

For each projection we calculated the change in estimated Quino distribution by estimating both geographic similarity and turnover. These two concepts are similar, but not identical.

1. Geographic similarity. We created a map that shows both current potential Quino distribution and future projected Quino distribution, taken from the median of all 704 future model outputs. For each $800 \mathrm{~m}^{2}$ grid cell, Quino was categorized as "present" if, for that pixel, more than $50 \%$ of the model outputs categorized that pixel as "suitable". Hence, the pixel was marked "present" if there was agreement across $>50 \%$ of outputs. This provided information on both the total area change between current and future projections, as well as the geographic placement of potential suitable habitat in both time periods.

2. Turnover is the percentage of the current range that will continue to be suitable in the future, calculated for each model individually. That is, for a given model, its 'current' projection is compared to its 'future' projection, and the loss of 'presence' pixels calculated. Note that the highest value that can be obtained is ' 1.0 ', since this metric estimates only loss of current area occupied, and does not consider any gains of suitable area outside the current projected distribution.

For the following reasons, results from using USA-only data are expected to differ from those using both USA and Mexican data:

1. They are likely to differ not only because the occupied grid cells may have different climate spaces, but also because the points sampled as pseudo-absences are 
likely to differ in climate space. Differences in climate space among pseudo-absences may actually have a much larger effect than that of known presences, because Baja California may contain somewhat more extreme hot/dry climates just outside of the buffer zone created around presence points than does the LA-San Diego region.

2. The timespan of the PRISM climate data (1970-2000) more closely matches the time span of our 'current' Quino distribution records (1990-2005) than does the WorldClim climate data, that goes two decades further back in time (1950-2000). Thus, the Mexican populations were characterized with older climate data than that of the USA populations, and with climate data that was more temporally distant from current Quino distribution data.

3. The NARCAP Climate outputs were calibrated with the PRISM dataset to give the high resolution climate projections used to project Quino distribution into the future. Using these outputs with SDMs built with WorldClim data will yield less reliable distribution projections than using them with SDMs built with the PRISM dataset.

The first point, that the two Quino datasets would differ in the climate information fed into the SDMs and therefore have different SDM outputs, carries no expectation of one being better than the other for projecting into the future. However, the second and third points lead to the conclusion that using the USA-only data will lead to more reliable future projections than using the combined USA-Mexican data. That is, the USA-only Quino data both better matches the timespan of the climate data and can use climate projections that have been calibrated to the same climate data used to build the SDMs. For these reasons, we provide the results of projected future Quino distribution in the main text from SDMs built with USA-only data, and results from using both USA and Mexican data in Online Resources.

\section{Molecular genetics}

In our molecular analyses we used ten microsatellite markers chosen as the most informative from a diversity of markers generated from P454-pyrosequencing of transcriptome. Details of technique are given in Mikheyev et al. (2010) and in Mikheyev et al. (2013). We used these markers to assess genetic similarity (Fst) values within and between two sets of $E$. editha populations. The first set comprised all eight Quino populations from which we have data, while the second comprised 18 non-quino E. editha populations recorded as feeding on Collinsia. We used all 26 populations to construct an NMDS plot illustrating the first two principal components of inter-population genomic
Table 1 Latitudes, longitudes and elevations of sites for which pairwise Fst values appear in Table 4; Quino populations in bold, non-Quino E. editha in plain text

\begin{tabular}{lllc}
\hline Population name & Lat & Lon & Elevation $(\mathrm{m})$ \\
\hline Mill Canyon & 38.473 & -119.51 & 2,050 \\
Indian Flat & 37.65 & -119.82 & 610 \\
Tamarack Ridge & 37.156 & -119.2 & 2,300 \\
Yucca Point & 36.827 & -118.89 & 1,250 \\
California Hot Springs & 36.058 & -118.91 & 955 \\
Walker Pass & 35.645 & -118.03 & 1,700 \\
Silverado Ranch & $\mathbf{3 3 . 7 3}$ & $-\mathbf{1 1 7 . 6 4}$ & $\mathbf{4 8 0}$ \\
Skinner & $\mathbf{3 3 . 5 9}$ & $\mathbf{- 1 1 7 . 0 6}$ & $\mathbf{4 2 7}$ \\
Terwilliger & $\mathbf{3 3 . 4 7}$ & $\mathbf{- 1 1 6 . 6 2 3}$ & $\mathbf{1 , 3 5 2}$ \\
Dulzura & $\mathbf{3 2 . 6 4}$ & $\mathbf{- 1 1 6 . 7 8}$ & $\mathbf{3 9 1}$ \\
Marron Valley & $\mathbf{3 2 . 5 7}$ & $\mathbf{- 1 1 6 . 7 5}$ & $\mathbf{3 1 1}$ \\
\hline
\end{tabular}

distances. We also used a restricted subset of the data (listed in Table 1) to make a table of genetic distances (Fst values). The restricted subset comprised the Collinsiafeeding populations geographically closest to Quino (south of Yosemite) and all Quino populations for which we had sample sizes greater than five individuals: three populations feeding principally on Plantago (Marron Valley, Dulzura and Lake Skinner), one population feeding principally on Antirrhinum and Plantago (Silverado) and one (Terwilliger) representing the "new" populations feeding principally on Collinsia.

\section{Host preference behaviour}

We used sequential encounter preference tests (Singer et al. 1992) to estimate oviposition preferences of wild-caught and lab-raised female Quino. We used as test plants Plantago erecta from a population used by Quino (Marron Valley), C. concolor from a population used by Quino (Barbara Trail) and Collinsia heterophylla from a population used by a different subspecies of $E$. editha (California Hot Springs). In each preference test, the butterfly was subjected to staged encounters with each of two hosts, in alternation, approximately every $20 \mathrm{~min}$. Attempts to oviposit were recorded as acceptances but oviposition was not permitted until the test was over. By preventing oviposition we were able to ask the butterflies how long they would search, accepting only their preferred host, before they reached the level of motivation at which either host would be accepted, whichever was next encountered. This time interval, termed a "discrimination phase," (Singer et al. 1992) is an heritable trait in E. editha, both within populations (Singer et al. 1988) and among them (Singer and Parmesan 1993).

We also made a video of a female Quino from a population feeding on the "new" host, C. concolor, in order to 
Table 2 Definitions of likelihoods from the IPCC guidance document on uncertainties for the fifth assessment report

\begin{tabular}{ll}
\hline Term & Likelihood of the outcome \\
\hline Virtually certain & $99-100 \%$ probability \\
Very likely & $90-100 \%$ probability \\
Likely & $66-100 \%$ probability \\
About as likely as not & $33-66 \%$ probability \\
Unlikely & $0-33 \%$ probability \\
Very unlikely & $0-10 \%$ probability \\
Exceptionally unlikely & $0-1 \%$ probability
\end{tabular}

Mastrandrea et al. (2010). "Likelihood... provides calibrated language for describing quantified uncertainty. It can be used to express a probabilistic estimate of the occurrence of a single event or of an outcome (e.g., a climate parameter, observed trend, or projected change lying in a given range). Likelihood may be based on statistical or modeling analyses, elicitation of expert views, or other quantitative analyses. The categories defined in this table can be considered to have "fuzzy" boundaries. A statement that an outcome is "likely" means that the probability of this outcome can range from $\geq 66 \%$ (fuzzy boundaries implied) to $100 \%$ probability." (Mastrandrea et al. 2010)

show how the host was physically handled as the insect prepared to oviposit and to compare this behaviour with that of insects known to be adapted to use the genus Collinsia.

Use of IPCC terminology to describe likelihoods

Terminology developed for the Intergovernmental Panel on Climate Change (IPCC) to describe the weight of scientific evidence for a particular result is useful here, in that it allows us to combine different types of evidence to draw a single conclusion as to how strongly the evidence supports that result. We use the likelihood metric that has been developed by IPCC "for communicating the degree of certainty in key findings, which is based on author teams' evaluations of underlying scientific understanding... (Likelihood estimates provide) quantified measures of uncertainty in a finding expressed probabilistically (based on statistical analysis of observations or model results, or expert judgment)." (Table 2; Mastrandrea et al. 2010).

\section{Results}

Observed population changes over time

Figure 1 shows the locations of Quino populations, colourcoded by the year of First Record for each population. We found a significant trend for First Records of Quino to be at higher and higher elevations over time (Figs. 1, 2). We analyzed this trend in two ways. First, we found a highly significant association between the date of First Record and the elevation at which the individual butterfly comprising that record was recorded (Fig. 2, $\mathrm{r}=0.60, d f=116$, $P<0.0001)$. Second, we grouped populations by date first recorded into three groups: 1890-1997, 1998-2009 and 2010-2013 (see "Methods"). We found that populations first discovered in the three time periods were significantly
Fig. 1 Map showing timing of first observation of Quino populations relative to elevation. Higher elevations are in lighter background colour. A small number of the northernmost extinct sites lie outside the map area. This contrasts with the map of Preston et al. (2012), which indicates patterns of extinctions (showing timing of last observations), rather than patterns of colonizations (timing of first observations)

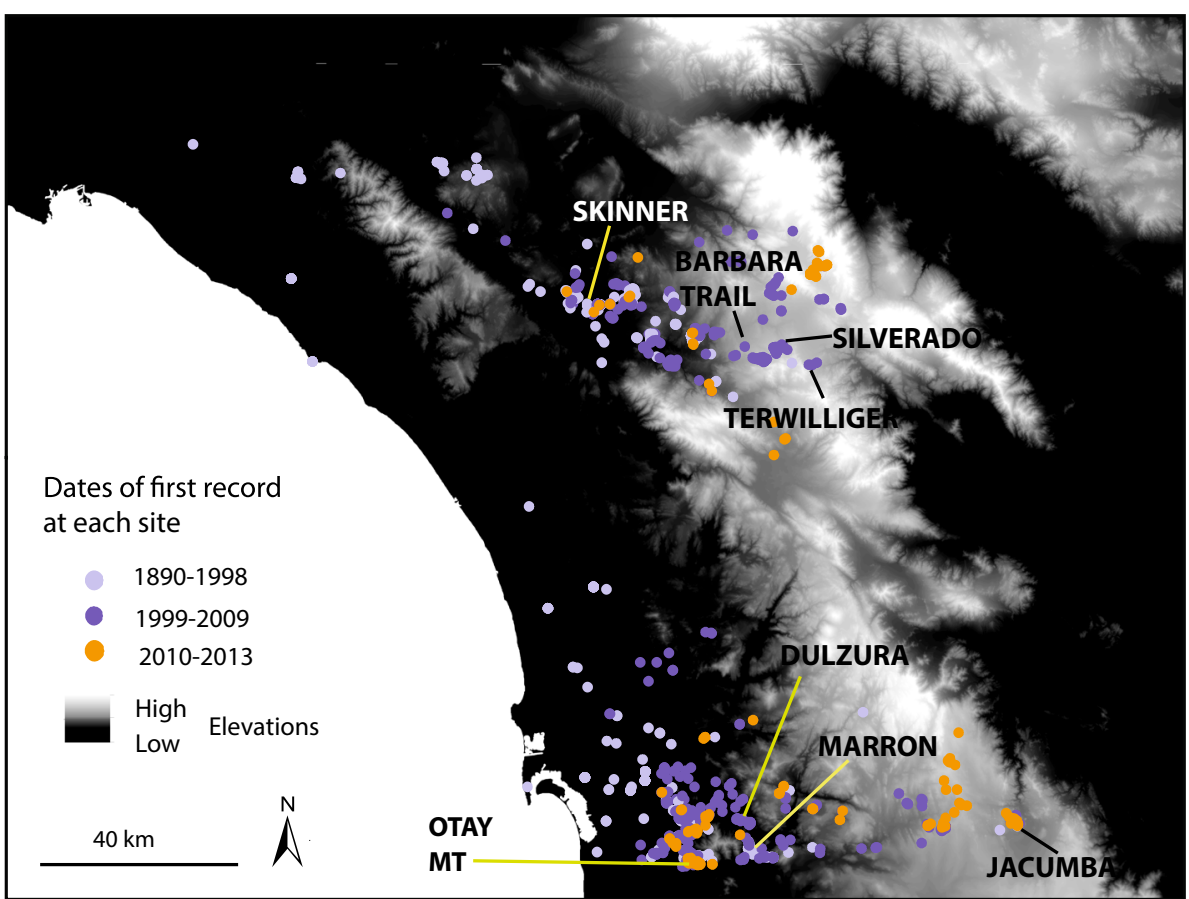




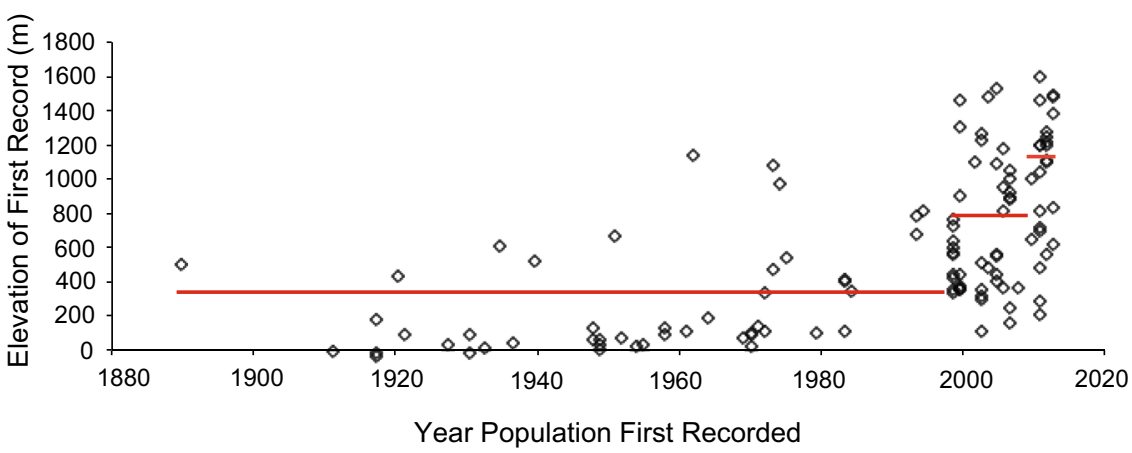

Fig. 2 Scatterplot of elevations of populations against year that population was first discovered (first recorded). Populations were placed into one of three groups depending on whether they were first discovered in the period 1890-1997, 1998-2009, or 2010-2013.

Table 3 Basic statistics for populations grouped by year of first record

\begin{tabular}{llll}
\hline $\begin{array}{l}\text { Year population was } \\
\text { first discovered }\end{array}$ & $1890-1997$ & $1998-2009$ & 2010-2013 \\
\hline $\mathrm{N}$ & 57 & 49 & 12 \\
Mean elevation $( \pm \mathrm{SE})$ & $360^{\mathrm{a}} \pm 41$ & $804^{\mathrm{b}} \pm 60$ & $1,164^{\mathrm{c}} \pm 88$
\end{tabular}

Populations were placed into one of three groups depending on whether they were first discovered in the period 1890-1997, 1998-2009, or 2010-2013. Mean elevation is significantly different across groups (weighted ANOVA, $d f=2,115, P<0.0001$ ). Superscript letters are different if there were significant differences in pairwise comparison (Tukey's HSD text, $P<0.01$ in all cases)
Mean elevation for each grouping is indicated with a red bar. Elevation and year of first discovery are highly significantly correlated $(\mathrm{r}=0.60, d f=116, P<0.0001)$

different in mean elevation, both overall and in every paired combination (Table 3; Fig. 2, weighted ANOVA, $d f=2,115, P<0.0001$ overall, $P<0.01$ for each pairwise test by Tukey HSD test). Because sample sizes differed considerably among groups, we also performed a Kruskal-Wallis rank test, with the same result $(\mathrm{H}=44.04$, $d f=2, P<0.0001)$.

We calculated mean elevations of the first adults recorded at each population. For populations known prior to 1998, the most recent data used by Pratt et al. (2001), the mean was $360 \mathrm{~m}$. Mean elevation of first adult sightings at new locations between 1998 and 2009 was 804 m, and the
Fig. 3 Current and future projected species distributions for Quino based on climatic niche models. Known historical records are shown with the ' + ' symbol. Current climate projections (blue shading) and future climate projections (orange shading) represent an ensemble of all model outputs, with "presence" indicated by blue or orange coloring if a grid cell was estimated as present in at least $50 \%$ of SDM models (i.e. anywhere from 50 to $100 \%$ of model agreement)

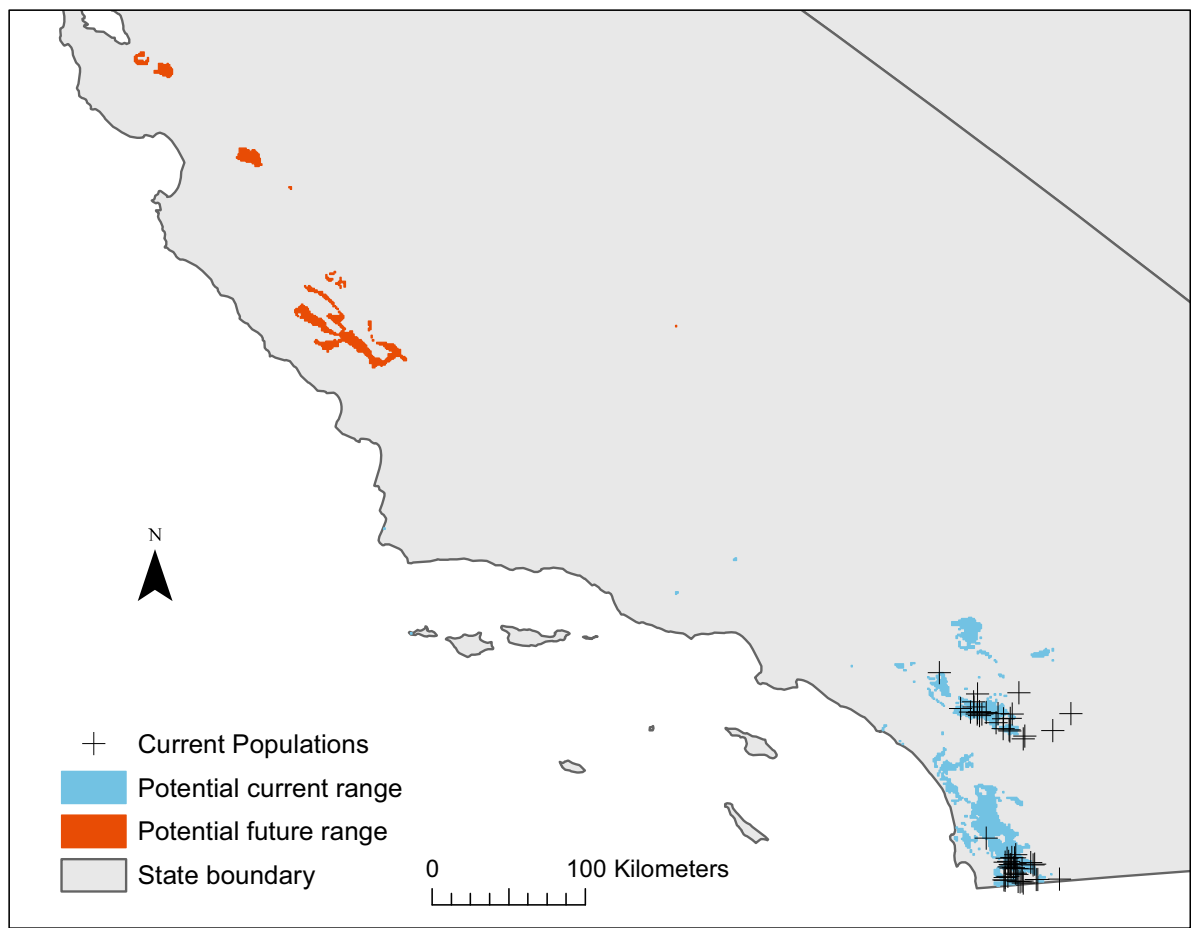




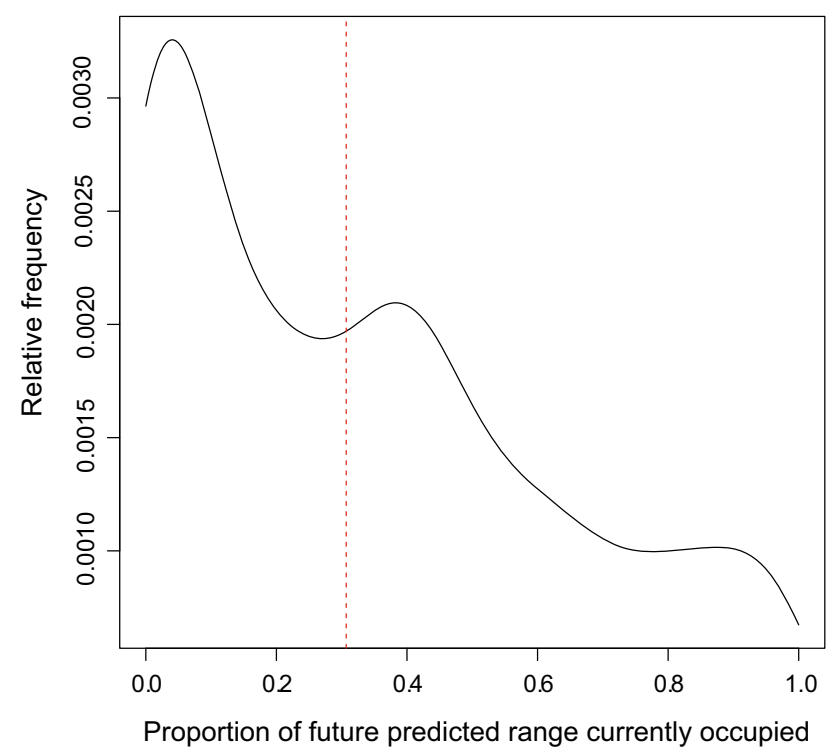

Fig. 4 Smoothed frequency histogram of species range turnover from 704 model outputs. The comparison, as in Fig. 3, is of current versus future projected species distributions for Quino based on climatic niche models

mean elevation of first adult sighting at new locations from 2010 to 2013 was $1,164 \mathrm{~m}$.

Current and future projected changes in Quino distribution

Figure 3 shows an ensemble projection map for which there was at least $50 \%$ agreement (and up to $100 \%$ agreement) across all 704 model outputs of future scenarios. In the Figure, the historic range of Quino completely loses suitable climate space by the mid-21st century, with appropriate climate space occurring approximately $400 \mathrm{~km}$ north of the historic range. All models for Fig. 3 were built using current USA populations. The ensemble projection map built upon both USA and Mexican current records is shown in Online Resource 1A.

Figure 4 shows the full range of model variability (the equivalent for the USA + Mexico models is shown in Online Resource 1B). The $y$-axis is the proportion of the model outputs with a given turnover, plotted against the proportion of the future projected range that is currently occupied (i.e. turnover). The red line is the median for all model outputs. The highest mode is close to zero, indicating that the most frequent projected turnover is effectively total loss of climate space in the historic range. The median is around 0.30 turnover, meaning that half of the projections show between 0 and $30 \%$ of the current potential range (based on climate space) having climatically suitable habitat in the future, and half are more optimistic.
Molecular genetics

Both Table 4 and Fig. 5 show that the recently discovered populations of Quino that use $C$. concolor cluster genetically with historically-known populations of Quino that use Plantago $s p$. and not with non-Quino populations of $E$. editha feeding on Collinsia sp.. Within Quino itself, the "new" Collinsia-feeding populations were not genetic outliers, but fit within the subspecies, clustering close to Plantago-feeding populations such as Marron Valley and Dulzura.

Host preference for oviposition

We preference-tested six adult females from two Plantagofeeding sites (Marron valley and Dulzura) on P. erecta and C. heterophylla. C. heterophylla is the principal host of $E$. editha at a Southern California site, California Hot Springs. We were able to test on $P$. erecta and $C$. concolor two females from Dulzura and a single female from a "new" population feeding on C. concolor, at Barbara Trail. Although this type of preference test frequently exposes strong oviposition preferences (Singer and McBride 2010), in our trials here, none of the butterflies distinguished between Collinsia and Plantago.

The video of oviposition on Collinsia parvifora by a butterfly from a Collinsia-feeding Quino population at Barbara Trail shows strong positive geotaxis and a large egg clutch laid as low on the plant as physically possible, on one of the cotyledons: https://www.youtube.com/ watch?v=c3YpvlSfm-Y.

\section{Discussion}

Butterflies are shifting their ranges world-wide

Butterfly ranges are dynamic and capable of rapid response to changing conditions, helping to place these animals at the forefront of research on range shifts responding to changing climate. Meta-analyses of butterfly data typically show mean range shifts that are substantial and significant, and greater than for other taxonomic groups. For example, DeVictor et al. (2012), summarizing results from 2,130 butterfly communities in Europe, estimated a mean northward range shift of $114 \mathrm{~km}$, compared to only $37 \mathrm{~km}$ for birds. There is less known about elevational shifts, but again butterflies appear to be moving in concert with regional climate change. For example, Wilson et al. (2007) estimated that the lower elevational range boundaries of a butterfly community in central Spain had risen by an average of $212 \mathrm{~m}$ in 30 years, compared to an expectation of $225 \mathrm{~m}$ from the regional temperature rise over the same 
Table 4 Pairwise genetic distances (Fst values) for selected Quino populations and non-Quino E. editha populations feeding on Collinsia spp

\begin{tabular}{|c|c|c|c|c|c|c|c|c|c|c|c|}
\hline & Dulzura & $\begin{array}{l}\text { Marron } \\
\text { Valley }\end{array}$ & Terwilliger & $\begin{array}{l}\text { Silverado } \\
\text { Ranch }\end{array}$ & $\begin{array}{l}\text { Lake } \\
\text { Skinner }\end{array}$ & $\begin{array}{l}\text { California } \\
\text { Hot Springs }\end{array}$ & $\begin{array}{l}\text { Indian } \\
\text { Flat }\end{array}$ & $\begin{array}{l}\text { Mill } \\
\text { Canyon }\end{array}$ & $\begin{array}{l}\text { Tamarack } \\
\text { Ridge }\end{array}$ & $\begin{array}{l}\text { Walker } \\
\text { Pass }\end{array}$ & $\begin{array}{l}\text { Yucca } \\
\text { Point }\end{array}$ \\
\hline Marron & 0.0034 & $\mathbf{0}$ & & & & & & & & & \\
\hline Terwilliger & 0.0657 & 0.0454 & $\mathbf{0}$ & & & & & & & & \\
\hline Silverado & 0.0396 & 0.0108 & 0.0007 & $\mathbf{0}$ & & & & & & & \\
\hline Skinner & 0.1452 & 0.0717 & 0.0764 & 0.0801 & $\mathbf{0}$ & & & & & & \\
\hline California Hot Springs & 0.1517 & 0.1648 & 0.2047 & 0.1759 & 0.2447 & 0 & & & & & \\
\hline Indian Flat & 0.1175 & 0.1232 & 0.1262 & 0.1283 & 0.135 & 0.073 & 0 & & & & \\
\hline Mill Canyon & 0.082 & 0.1205 & 0.1541 & 0.1411 & 0.2139 & 0.077 & 0.0849 & 0 & & & \\
\hline Tamarack Ridge & 0.1413 & 0.1267 & 0.1119 & 0.1009 & 0.1272 & 0.120 & 0.0202 & 0.1449 & 0 & & \\
\hline WalkerPass & 0.181 & 0.1565 & 0.1954 & 0.1712 & 0.212 & 0.110 & 0.0916 & 0.1499 & 0.1127 & 0 & \\
\hline Yucca Point & 0.1438 & 0.1416 & 0.1258 & 0.1291 & 0.1464 & 0.104 & 0.0079 & 0.1358 & 0.0427 & 0.1051 & 0 \\
\hline
\end{tabular}

Within-Quino Fst values in bold text; Fst values involving non-Quino populations in plain text

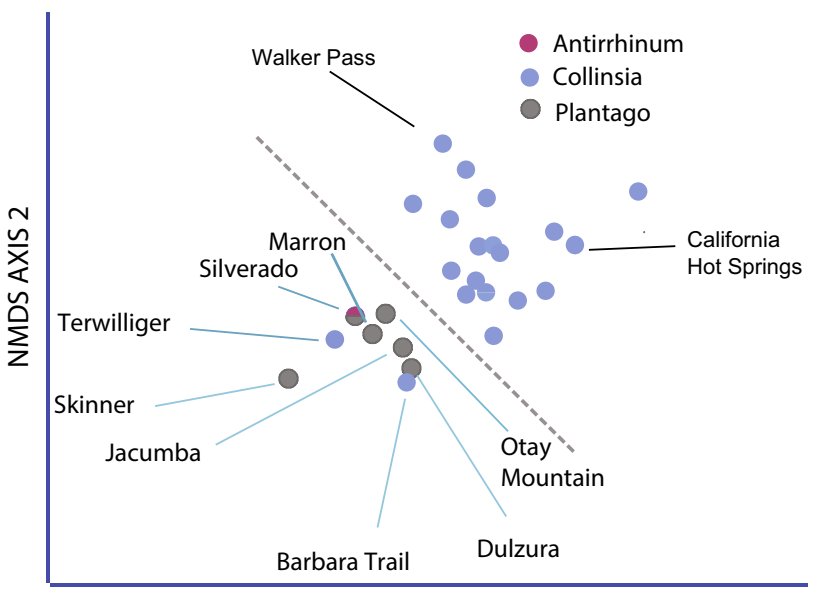

NMDS AXIS 1

Fig. 5 NMDS plot showing genetic relationships among populations of Quino and of non-quino populations that use Collinsia as a hostplant. Grey dots indicate populations feeding principally on Plantago, blue dots show Collinsia as the principal host, purple indicates Antirrhinum. The dashed line separates Quino populations (below the line) from other Collinsia feeding populations of E. editha not included in the subspecies E. e. quino (above the line). The stress value of this plot is 0.3585069

period $\left(1.3{ }^{\circ} \mathrm{C}\right)$. Tropical studies are rarer than temperate, but a notable exception is Chen et al (2011b), who compared recent range limits of geometrid moths on Mt Kinabalu (Malaysia) with samples taken in 1965. They found a mean upward shift of the upper and lower boundaries by 83 and $86 \mathrm{~m}$ respectively. Closer to our study area, the best community-level historical records in California are from the northern part of the state, gathered by Art Shapiro and colleagues. Like the studies we've cited above, these analyses show upward elevational shifts consistent with responses to warming climate (Forister and Shapiro 2003; Forister et al. 2010).
In community-level studies it's not easy to control for or eliminate habitat degradation as a cause of changes in range limits. This problem has been tackled in diverse ways. Konvicka et al. (2003) implicated climate change because diverse species with diverse range limits showed similar elevational range shifts. Wilson et al (2005) observed that congeners of the range-contracting species that used the same host plants continued to exist at lower elevation, below the contracting boundaries. Parmesan et al. (1999) explicitly excluded species for which habitat loss in the vicinity of range boundaries risked being a confounding factor. In single-species studies it's easier to deal with habitat change; both Franco et al. (2006) studying Erebia epiphron in the UK and Scalercio et al. (2014), studying Erebia cassioides in Italy, felt that they were able to discount habitat changes as causes of uphill range shifts, principally because they were in traditionally-managed montane habitats. Interestingly, E. cassioides shifted its range relative to treeline, illustrating that, as we would expect, the butterfly range was more labile than that of the trees; the proportion of individuals recorded above treeline rose from $56 \%$ in 1975 to $>99 \%$ in 2012.

We argue that Quino currently manifests an elevational range margin that is expanding under warming regional climate. Butterflies have already contributed valuable information about ecological and evolutionary dynamics of this type of range margin. In particular, poleward expansion of the Brown Argus butterfly in the UK was facilitated by a host shift in populations at the northern range edge (Thomas et al 2001). Insects from the expanding part of the range showed increased homogeneity of oviposition preference, specializing on a widely-distributed host (Bridle et al. 2014). This change represented a decrease in local adaptation to host composition of habitats, accompanied and presumably caused by an increase in dispersal ability (Bridle et al 2014). When transplanted back to the 
traditional part of the range in the UK, females from the range margins showed reduced fitness compared to local insects, whereas insects gathered within the traditional range and transplanted to the expanding periphery suffered no such deficit. The expanding populations had lost some of their ability to adapt to local conditions (Buckley and Bridle 2014).

Prior work on range shifts in E. editha and its Quino subspecies

The intensive study of E. editha by Parmesan (1996, 2003, 2005) showed both elevational and latitudinal shifts, with the mean location of an extant population occurring $124 \mathrm{~m}$ higher and $92 \mathrm{~km}$ further north in the early 1990's than in historical records from museums and private collectors (dating back to 1860). This study controlled for changes in distribution due to habitat destruction and degradation by removing degraded sites from the final analyses. Thus, populations that had been rendered extinct due to direct human degradation of the habitat were not included; only sites that remained suitable habitat for E. editha (estimated from density and quality of potential host plants and nectar sources) were included, whether or not the butterfly population was currently present or currently extinct. This analysis across the species range included the Quino subspecies, but used only 14 Quino populations (8 in Mexico, 6 in the USA). The majority of historical Quino sites were excluded from the database because they were no longer suitable habitat, usually as a direct result of late 20th century urbanization in the Los Angeles-San Diego corridor.

For these reasons, Parmesan (1996) did not address the question of whether Quino, as a separate entity from other subspecies, was shifting its range. This question was first proposed as a result of the discovery by Pratt et al. (2001) and Pratt and Pierce (2008) of Quino in the Anza area, to the east of the traditional range, at higher elevations than previously-known populations and using hosts (Antirrhinum coulterianum and $C$. concolor) not previously known to be used by Quino (Figs. 1, 2). Prior to these reports only a single individual had been reported from this region, in the mid-1980s (J. Emmel, pers. comm).

Multiple lines of evidence support a recent elevational range shift, accompanied by a host shift

\section{Support from occurrence records for Quino elevational expansion}

Working across the entire historic and current range of Quino, we found an overall significant upward trend through time in elevations of newly-discovered populations. In a categorical analysis, organizing these same data into three relevant time periods, we showed that populations discovered between 2010 and 2013 were $45 \%$ higher than the mean elevation of those reported between 1998 and 2009, which in turn were nearly double the mean elevation of populations discovered prior to 1998 (Table 3; Figs. 1, 2). The 2010-2013 data also show First Records of Quino at moderate to high elevation in areas of eastern Riverside County, Southern Riverside County and eastern San Diego County that are entirely devoid of prior observations, even for the 1998-2009 period (Fig. 1).

How might we interpret the high mean elevation of first records in 1998-2009, compared to older records? Part of the difference stems from the obvious effect of urbanization on colonization in low-lying areas, part could result from expansion of human exploration for Quino following its listing as endangered in 1997 and part could represent an elevational range shift by the butterfly. It isn't feasible to dissect these causes, all of which lead to the same prediction. In contrast, changes occurring more recently, within the 2010-2013 period, are more straightforward to interpret. First, major destruction of low elevation habitats that precludes new colonizations at low elevation was essentially complete by 1998. Second, we consider it unlikely that any increase in exploration for new Quino populations, triggered by listing in 1997 and by the publication of Pratt et al. (2001), would continue unabated for more than a decade. Therefore, we regard the continued increase in elevation of First Records in 2010-2013, compared to 1998-2009, plus the recording of Quino in three new high-elevation areas in 2010-2013, as unlikely to be artefacts due to altered effort or sampling, but much more likely to be manifestations of an upwardly colonizing wavefront, consistent with expectations from regional climate warming. We consider it very likely ( $>90 \%$ probability) that such a true upward range shift is now occurring.

\section{Apparent host shift accompanying elevational shift}

The genus Collinsia has long been known to be used by non-quino subspecies of E. editha (Singer 1971) but, prior to the report by Pratt and Pierce (2008) was not known as a host of Quino. The primary host plants historically known to be used by Quino were annual species in the genus Plantago, principally $P$. erecta. Newly discovered populations of Quino used C. concolor, Antirrhinum coulterianum and Plantago patagonica as hosts (Pratt et al. 2001; Pratt and Pierce 2008). These discoveries prompted further search, and Pratt (pers. comm.) reports finding several egg/ larval masses on Cordylanthus in Marron valley (San Diego County), a region where the insect had previously been thought monophagous on Plantago. 
Collinsia and Antirrhinum are spring annuals that senesce in the California summer, but both are less ephemeral than the Plantago spp. used by Quino. Cordylanthus can be even more long-lived than Antirrhinum. Occasional use of these less ephemeral hosts in the traditional range may help explain the persistence of the butterfly through years when the principal local host, Plantago, has seemed too scarce and/or has senesced too quickly to support the insects' life cycle. Nonetheless, Plantago is currently the principal host of lower elevation Quino populations in the "traditional" range, and the use of Collinsia in the newly- colonized higher elevation populations may represent a major host shift. Use of this host mitigates risk to Quino of extinction in response to near-term anthropogenic climate change, both because of delayed senescence of Collinsia relative to Plantago and because Collinsia exists in moderate to high densities at higher elevations than does Plantago, allowing Quino to expand further upwards than it could have done if confined to Plantago habitats.

In the following sections we assess the likelihood that a recent host-shift towards Collinsia has indeed occurred. We do so by bringing together independent lines of evidence from genetics and behaviour.

\section{Genetic evidence for frequent host shifts in E. editha}

Within the species E. editha, in a study conducted on 40 populations distributed across more than $1,000 \mathrm{~km}$ by $400 \mathrm{~km}$, population genetic differentiation was strongly and significantly associated with geographic distance; however, after controlling for this isolation by distance, there was no residual signal of host-associated genomic differentiation (Mikheyev et al. 2013). Host shifts appear to be common in this species. Indeed, $E$. editha has twice been directly observed to undertake evolutionary host shifts in less than ten generations, each time in response to (non-climatic) anthropogenic disturbance (Singer et al 1993). Therefore, the capacity of the subspecies Quino to host-shift should come as no surprise.

\section{Genetic evidence for coherence of quino populations}

In parallel with the larger genetic study cited above, Quino populations also fail to separate genomically according to the hosts that they use. More specifically, two "new" high elevation populations of Quino that used principally Collinsia (Terwilliger Valley and Barbara Trail) clustered with lower-elevation populations of mostly Plantago-feeding Quino and not with other populations of E. editha feeding on Collinsia (Table 4, Fig. 5).

\section{Behavioural evidence for recent host shift}

We asked whether Collinsia-feeding Quino resembled other Collinsia-feeding E. editha in host adaptations. The less specific their adaptations to Collinsia, the less likely it is that they have a longstanding association with this plant as a principal host.

Oviposition preference Oviposition preferences of Quino females for Plantago versus Collinsia have been weak or absent. In a prior study, seven Quino from Lower Otay showed weak preferences for P. erecta over Collinsia tinctoria (Singer et al. 1991). In the present work, eight Quino from Plantago-feeding populations expressed no preference between their principal host, $P$. erecta, and Collinsia (C. concolor or C. heterophylla). A single female from a $C$. concolor-feeding site likewise failed to discriminate between $P$. erecta and $C$. concolor. In contrast, females from non-Quino Collinsia-feeding populations have shown strong preferences for their own host genus over Plantago (Singer 1971; Singer et al. 1991).

Taken together with prior work on oviposition preference and dispersal (Hanski and Singer 2001 and refs therein), these results indicate that non-Quino females adapted to Collinsia would respond to a habitat containing only Plantago by emigration rather than by delayed oviposition. In contrast, all tested Quino females, in both this study and the previous one (Singer et al. 1991) would readily oviposit on either genus. Thus, no evolution of preference would be necessary for Quino to colonize Collinsia from Plantago or vice versa.

Geotaxis and clutch size Field experiments have shown that differences among $E$. editha populations in egg height and clutch size represent adaptations to use specific hosts (Singer and McBride 2010; McBride and Singer 2010; Bennett et al. 2015). Typically, females in Collinsia-feeding populations laid small clutches (4-6 eggs) more than $3 \mathrm{~cm}$ from the ground. This behaviour was adaptive: on Collinsia, larger groups suffered higher larval mortality and larvae feeding closer to the ground suffered lowerquality diet (McBride and Singer 2010). Among more than 20 non-Quino Collinsia-feeding populations where we have found egg clusters in the field, we know only two, at Walker Pass and Bircham Flat in the eastern Sierra, where eggs were generally laid low (Bennett et al. 2015). In contrast, eggs laid by Quino on Plantago in the field have been in larger clutches than typical of Collinsia-feeding insects (mean clutch size $=23$ eggs, range 11-34, $\mathrm{n}=6$ clutches) and laid close to the base of the plant with mean height above the ground around $0.3 \mathrm{~cm}$ (Fig. 6; Bennett et al. 2015). Low oviposition heights are achieved by means of positive geotaxis (video S1 attached to McBride 
Fig. 6 Photo of a female $E$. editha quino from Dulzura laying eggs on $P$. erecta. This female is from a population monophagous on $P$. erecta and her oviposition behavior (laying large egg clusters close to the ground) is identical to other Plantago-feeding E. editha populations, and dissimilar to non-Quino Collinsia-feeding populations (laying small egg clusters high on the plant)

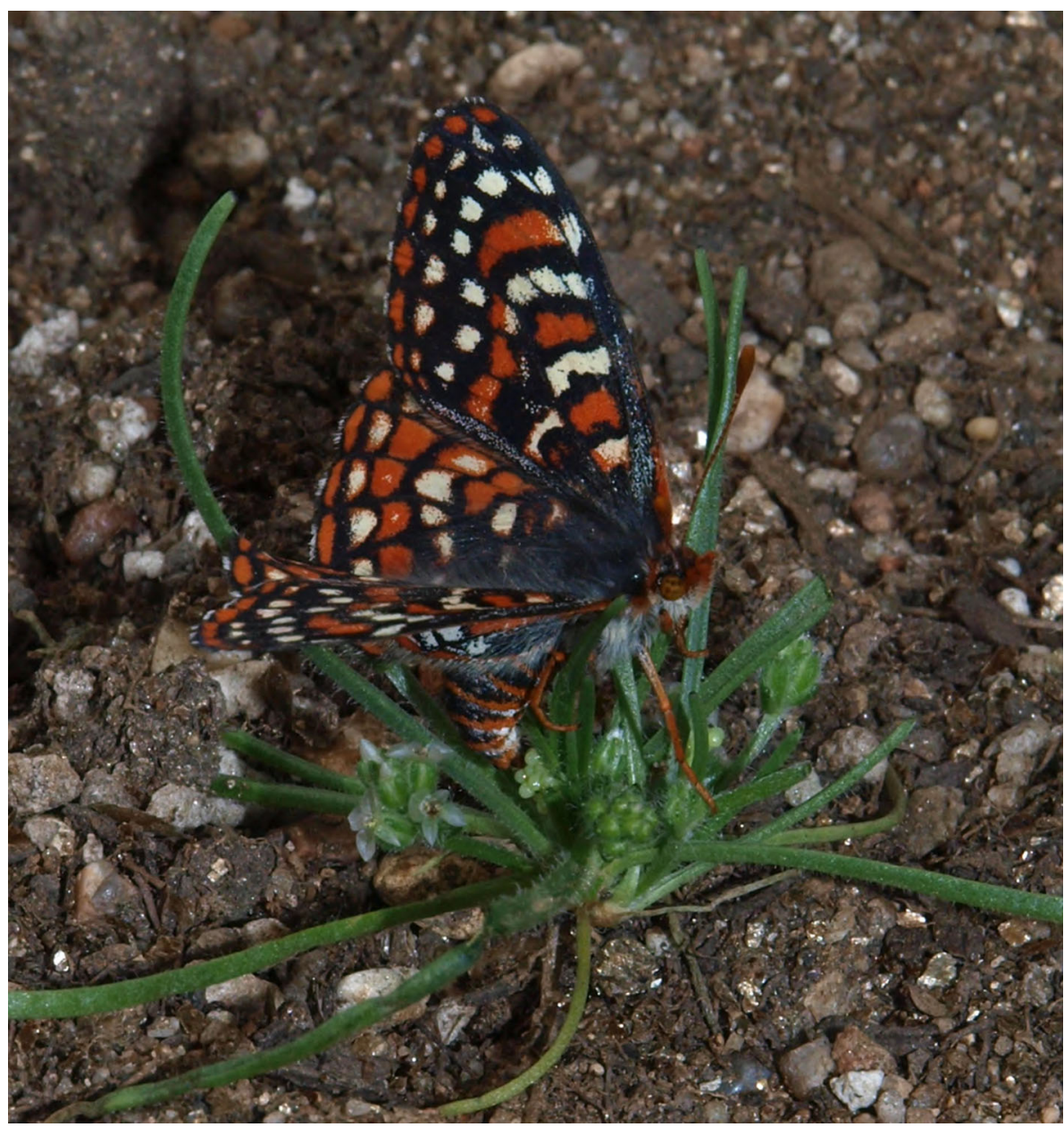

and Singer 2010). In contrast, high oviposition heights result from females simply laying where they alight (i.e. no geotaxis-see video at https://www.youtube.com/ watch?v=pXT4qinQ0KM.

We have no quantitative survey of egg-heights among Collinsia-feeding Quino, but we recorded a video of oviposition on Collinsia by a female Quino from a Collinsiafeeding population (Barbara Trail) in the "new" part of the range: see https://www.youtube.com/watch?v=c3YpvlSfmY. The female Quino in the video had previously shown no preference between $P$. erecta and $C$. concolor, accepting both hosts readily. The video records her responses to a structurally similar Collinsia, C. parviflora, a host of E. editha in the Eastern Sierra Nevada. The butterfly shows strong positive geotaxis and lays a large egg clutch as low on the plant as possible, on one of the cotyledons. She also appears to handle the plant clumsily, digging her ovipositor into the ground while searching for the base of the plant and almost losing the plant at one point in the sequence. In sum, the female appears to treat the Collinsia plant as though it were a Plantago. This observation complements the molecular evidence in lending credence to the hypothesis that Plantago- feeding lies in the butterfly's recent ancestry, although no Plantago was present in the population (Barbara Trail) at which the butterfly was caught.

Given the strong documentation (direct observation) of rapid host shifts in the species $E$. editha, genetic coherence of the newly discovered populations within the traditional Quino group, and behavioural evidence that insects from the "new" populations using Collinisa were not specifically adapted to use Collinsa, we conclude that it is at least likely ( $>66 \%$ probability), and arguably very likely, that Quino has recently expanded its host range in concert with its elevational range shift. We make no implication that evolution of host adaptation was necessary to achieve this host shift; rather the opposite is implied, that the shift was possible using existing behavioural plasticity.

Innovative strategy for recovery: adaptive management in response to a dynamic situation

Regardless of the cause of Quino's current distribution, it is clear that, following massive population destruction in its 
Fig. 7 Map of newlydiscovered populations of the Quino checkerspot butterfly (Euphydryas editha quino) and proposed Critical Habitat units (prior to regulatory exclusions). Region shown is along the mid-eastern edge of the historical species' range, largely in Riverside County. Elevation generally increases as you move from the west to the northeast. Pale yellow polygons are sites known to be occupied by Quino prior to 2003, orange polygons are sites discovered from 2003 to 2012. Greenstriped polygons indicate proposed 2008 Critical Habitat units

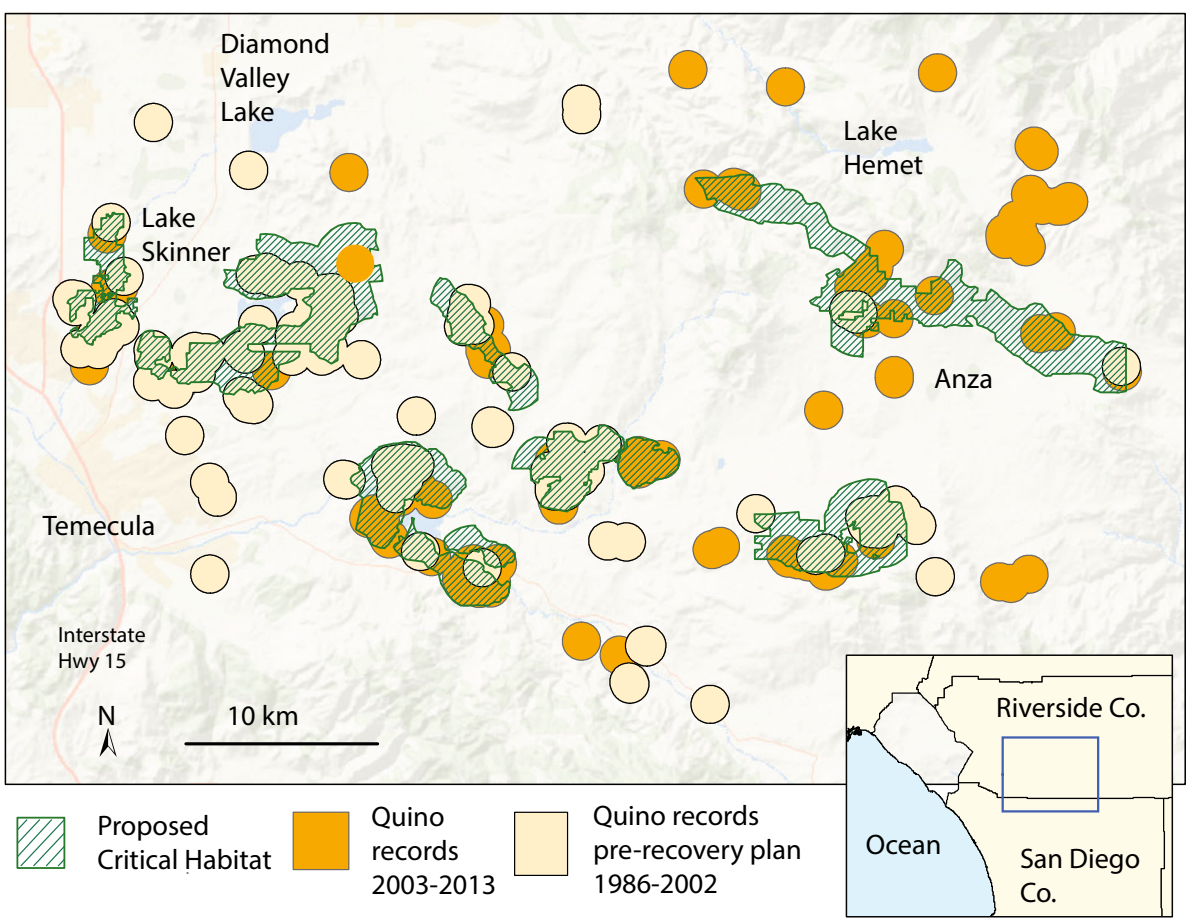

traditional range, Quino is currently surviving at moderate densities at several sites in areas where no established populations had previously been recorded. It seems likely that protection of areas outside the known historical range (Pratt et al. 2001; USFWS 2008, 2009a, b) are likely to provide climate refugia from at least near-term climate change and will be crucial for Quino's long-term persistence.

In order to address and anticipate climate change impacts, recent Critical Habitat designations for Quino took non-traditional and politically unorthodox steps to protect habitat where occupancy had not been demonstrated. In 2009, an approximately 5,617 hectare area was designated as a critical habitat unit (Unit 7) at elevations above and north of the town of Anza (USFWS 2009b; Fig. 7). Unit 7 was described as under-surveyed, likely to support a larger population than indicated by reported observations alone, and at the leading edge of an ongoing upward shift in Quino's elevation range (USFWS 2009b). The critical habitat rule (USFWS 2009b) stated "we expect loss of lower elevation and lower latitude populations will continue in this subspecies' range as incidences of aboveaverage temperatures, drought conditions, and extreme weather events continue to increase" and that Unit 7 was designed to connect a recognized core population near Anza to areas where Quino had been observed higher in elevation. Unit 7 included areas "outside the geographical area presently occupied by the subspecies" (USFWS 2009b), highlighting that such proactive measures are fully within the scope of the existing legal framework of the Endangered Species Act.

The future of Quino

\section{Observed and future projected trends in climate across Quino's range}

In Tables 5 and 6, we summarize observed and projected trends in climate for the southern California region encompassing Quino's historic and current distributions. This information is taken from Working Group I of the IPCC Fifth Assessment Report (Collins et al. 2013; Hartmann et al. 2013; Kirtman et al. 2013). Annual mean temperature has significantly increased over the 20th $\mathrm{c}$ (by $0.8-1.75^{\circ} \mathrm{C}$ ), and there is strong agreement among climate models that this trend will continue, with an additional rise of $0.75-1.0^{\circ} \mathrm{C}$ by 2035 and $1.25-4.5^{\circ} \mathrm{C}$ into the $22 \mathrm{nd}$ century. The geographical region encompassing Quino's range has experienced an increase in frequency of precipitation extremes (both heavy rainfall and severe drought), particularly in the past 30 years (Hartmann et al. 2013). The projected changes in precipitation are small and variable over the next 30 years, but converge on a wetter winter and a drier spring by 2200 (Collins et al. 2013; Kirtman et al. 2013). Quino population dynamics are strongly determined by the length of time to senescence of its annual host plants, that in turn is very sensitive to both the total precipitation as well as the timing of winter and 
Table 5 Observed trends in climate for the southern California region containing Quino

\begin{tabular}{ll}
\hline Observed Climate Trends & $\begin{array}{l}\text { Time period of } \\
\text { data set }\end{array}$ \\
\hline $\begin{array}{l}\text { Increased annual mean temperature: } \\
0.8-1.75{ }^{\circ} \mathrm{C}^{*}\end{array}$ & $1901-2012$ \\
$\begin{array}{l}\text { Decreased mean annual precipitation: } 5-10 \mathrm{~mm} / \\
\text { decade }\end{array}$ & $1901-2010$ \\
$4-8$ fewer extreme cold nights* & $1951-2010$ \\
$0-4$ fewer extreme cold days* & $1951-2010$ \\
$4-8$ more hot nights* & $1951-2010$ \\
$0-4$ more hot days* & $1951-2010$ \\
$0-5 \%$ increase heavy precipitation events & $1951-2010$ \\
$0-5 \%$ increase daily precipitation intensity & $1951-2010$ \\
$0-5 \%$ increase annual maximum number of & $1951-2010$ \\
consecutive dry days & \\
\hline
\end{tabular}

Results shown are from the region that encompasses the USA distribution of Quino as of 2014. Results are from three data sets (HadCRUT4, MLOST, and GISS; Hartmann et al. 2013). The range of results across all three data sets are given. Trends that are statistically significant at $P<0.10$ are noted with an asterisk

Table 6 Future climate change projections for the Quino region

\begin{tabular}{lll}
\hline $\begin{array}{l}\text { Near-term Climate } \\
\text { Projections } \\
(2016-2035)^{\mathrm{a}}\end{array}$ & $\begin{array}{l}\text { Medium Term Climate } \\
\text { Projections } \\
(2081-2100)^{\mathrm{b}}\end{array}$ & $\begin{array}{l}\text { Long-term } \\
\text { Climate } \\
\text { Projections } \\
(2181-2200)^{\mathrm{b}}\end{array}$ \\
\hline $\begin{array}{l}\text { Increased summer and } \\
\text { winter mean }\end{array}$ & $\begin{array}{c}\text { Increased annual mean } \\
\text { temperature: }\end{array}$ & $\begin{array}{l}\text { Increased annual } \\
\text { mean }\end{array}$ \\
temperatures: & $1.25-4.5{ }^{\circ} \mathrm{C}^{\mathrm{e}, *}$ & temperature: \\
$0.75-1.0^{\circ} \mathrm{C}^{\mathrm{c}, *}$ & & $0.75-8.0^{\circ} \mathrm{C}^{\mathrm{e}, *}$ \\
$10 \%$ decrease in & From $10 \%$ decrease to & $\begin{array}{l}\text { Increased winter } \\
\text { precipitation: }\end{array}$ \\
precipitation in each & $10 \%$ increase in & $20-40 \%{ }^{\mathrm{d}}$ \\
of 4 seasons $\mathrm{s}^{\mathrm{c},}$ & precipitation for & \\
& winter & \\
& Decreased spring & Decreased spring \\
& precipitation: & precipitation: \\
& $20-30 \%{ }^{\mathrm{d}}$ & $30-40 \%{ }^{\mathrm{d}, *}$ \\
\hline
\end{tabular}

${ }^{\mathrm{a}}$ Kirtman et al. (2013); ${ }^{\mathrm{b}}$ Collins et al. (2013). Results represent the ensemble mean of the Coupled Model Intercomparison Project Phase 5 (CMIP5) climate model outputs for the Representative Concentration Pathways (RCPs) ${ }^{\mathrm{c}} 4.5,{ }^{\mathrm{d}} 8.5,{ }^{\mathrm{e}} 2.6-8.5$. For future projections, data from Baja, Mexico was insufficient, therefore the GCM results below refer only the portion of Quino's range that is in the USA. An asterisk (*) indicates $90 \%$ of models agree on the sign of change with little variance among models (i.e. mean projected values deviate from past (simulated 1986-2005) by at least two standard deviations. A question mark (?) indicates large model disagreement (i.e. projected changes are small compared to variability amongst model outputs)

spring rainfall events. With winter and spring rainfall appearing to be moving in opposite directions, we expect that the impacts of these changes will ultimately depend on patterns of change in specific rainfall events.
Current and future warming trends, particularly in late winter and early spring, are expected to speed up host plant senescence more than larval development, reduce the window of time for pre-diapause larval feeding, and so increase pre-diapause larval starvation rates, and increase probabilities of population extinctions (Weiss et al. 1988; Hellmann 2002; Singer and Parmesan 2010). Changes in rainfall may either exacerbate or mitigate these temperature effects, depending on the exact timing of rainfall events during crucial life history stages for both the plants and the butterflies.

\section{Implications of climate projections for conservation of Quino}

Although the median model output shows around $30 \%$ of current potential range (Fig. 4) to remain suitable, the most frequent (modal) result shows zero overlap between the two ranges. The consensus in Fig. 3, in which the future range is indicated by pixels that were occupied in at least $50 \%$ of outputs, places the future position of Quino's climate envelope far to the north of the present range, in the California coast range between Morro Bay and San Francisco Bay.

The details of future projected distributions differ somewhat depending on whether the models were built upon current records from only the USA (Fig. 3) or from both the USA and Mexico (Online Resource 1A). However, both distributions are far to the north of Quino's current range, and so these differences do not affect our principal conclusions.

In common with all projections of future species distributions, whether process-based or climate envelopebased, our prediction that Quino's projected future range should contain suitable habitat is based on several assumptions:

1. The recent distribution of Quino reflects its climatic requirements; we justify this assumption from the rapidity of climate responses shown by butterfly ranges in general (deVictor et al. 2012).

2. Quino will not evolve to modify its climate envelope; we justify this assumption from the fact that the vast majority of responses to warming climate have been ecological rather than evolutionary (Parmesan 2006; but see Bridle et al. 2014 and Buckley and Bridle 2014 for an exception).

3. The predicted climatically-suitable range will contain ecologically suitable habitat patches (Hill et al. 2002); we justify this assumption from the ability of Quino to inhabit diverse habitats and feed on several host genera. We note that Preston et al. (2008) classified Quino habitat as scrub and eliminated grassland and 
forest habitats from their predicted range as unsuitable. However, in Mexico we have observed Quino populations in both grassland (Valle de Trinidad) and open forest (El Condor), so we view Preston et al's classification of Quino habitat as overly restrictive and hence pessimistic.

Although our projections of future Quino distribution (Fig. 3) are based solely on climatic characteristics, the general areas in this projection overlap with the current distributions of unnamed E. editha populations in the coastal hills north of Morro Bay and of the Bay Checkerspot, whose principal host is $P$. erecta, in common with that of low-elevation Quino. It lies outside our present scope to ask whether non-Quino ecotypes of $E$. editha currently inhabiting the predicted future Quino range are expected to have moved on by 2050, leaving unoccupied habitat for Quino to colonize.

\section{Management for Quino into the future: a long-term role for assisted colonization}

The case of the Quino checkerspot is thought-provoking. Climate change has not been an important cause of its decline up to the present (Preston et al. 2012), yet its biology, especially its year-to-year variation in phenological asynchrony with its annual hosts (Singer and Parmesan 2010 and refs therein), clearly marks it as climate-sensitive and vulnerable to expected climate warming. In this circumstance, should we concentrate on protecting Quino in its traditional strongholds, in Mexico and nearby sites just across the border in the USA? Or should we orient conservation actions by accepting as our starting point the apparent shift of the insect's principal concentration to higher elevations, and anticipate further shifts in altitude and latitude with expected further climate warming?

In favour of concentrating conservation efforts in traditional strongholds, there is evidence that actions to reverse ecosystem degradation can enhance in situ resilience to climate warming (Parmesan et al. 2013). As an example, restoration of degraded habitat for Quino in San Diego county by de-fertilization and creation of vernal pools has been successful in recreating an entire community of endangered species (Mark Dodero, personal communication). However, this restoration was expensive (\$1 million/acre) and continued intervention will be necessary to counter the malign influence of continued nitrogen deposition from atmospheric pollution and related invasion by exotic plants. Our modelling results indicate that this approach would involve attempting to maintain the insect in areas where its climate-space will continue to deteriorate, such that long-term prospects would be pessimistic.
In favour of the second approach that's proactive with respect to climate change, it has become more and more clear that butterflies, in general, are highly climate-sensitive organisms and are already responding to regional anthropogenic warming by range shifts. In areas where sufficient data exist and greenhouse-gas-driven warming has occurred, notably in Europe, the type of range shift documented by Parmesan (1996) for E. editha, with a shift in the mean location of an extant population, has become very frequent. DeVictor et al (2012) surveyed 2,130 butterfly communities from 1990 to 2007 and found a range shift of this type averaging $114 \mathrm{~km}$ across all communities.

The newly discovered high elevation populations obviate any need by Quino for short-term assisted colonization. However, in the medium term, a northward range shift in the direction of our predicted future range would require such assistance, at least in crossing the Los Angeles area, after which the insect may be able to make its way further north by "island-hopping" between suitable habitat patches.

Assisted colonization is still controversial in the USA (Schwartz et al. 2012). However, if it does become an accepted strategy, butterflies are prime candidates for it. They are unlikely to damage recipient communities, they are easy to capture and move, and many species are also easy to culture (Hoegh-Guldberg et al. 2008). Assisted colonization has been successfully used in butterflies with circumstances analogous to those of Quino (Willis et al. 2009) and Quino itself has been successfully cultured (Miller et al. 2014). A congener, Euphydryas gilletti, was artificially transported by Paul Ehrlich from Wyoming to Colorado in 1977 (Holdren and Ehrlich 1981; Boggs et al. 2006) and at last report (McCoy et al. 2014) was persisting at its site of introduction without spreading to other apparently suitable areas. While the need for assisted colonization is no longer pressing for Quino, our modeling results suggest that it will eventually be required if we are to ensure persistence of Quino through the current century.

\section{Conclusions}

There is strong agreement amongst conservation biologists that to minimize loss of biodiversity in the face of rapid climate change we need to promote climate-smart, landscape-level habitat conservation and restoration (Parmesan and Galbraith 2004; Lawler 2009; Mawdsley et al. 2009; Heller and Zavaleta 2009; Dawson et al. 2011; Gillson et al. 2013). The case of the Quino checkerspot, illustrated here, demonstrates that even species thought to be wellunderstood can respond adaptively in ways that surprise experts. Yet, hand-in-hand with this surprise combination 
of range shift and host shift, analogous to that achieved by the Brown Argus butterfly in the UK (Bridle et al. 2014), is the caveat that for Quino to achieve this feat, it required relatively undeveloped landscape within both its expanding range and that part of the traditional range that served as a source for the expansion. Without suitable habitats within dispersal range, there would have been no pleasant surprise. The surprise also depended on the fact that, unlike some other ecotypes of the same butterfly species which have strong host preferences, Quino's preferences are so weak as to enable it to colonize a novel host, Collinsia, without evolving. The result is that butterflies using Collinsia appear quite poorly adapted to their host. It is interesting to observe that this does not prevent them from developing denser populations on Collinsia than currently exist on the "traditional" host, Plantago, to which the insects seem better-adapted. The moral here is that individuals do not need to be pre-adapted to novel environments in order to colonize beyond historic range boundaries; they merely need to survive.

The fundamental conservation message from this example is that we need to increase connectivity among habitats and protected areas and increase species' in situ resistance and resilience to climate change by improving the health of populations, species, and ecosystems. We also show that, while use of species distribution models is helpful to provide a broad brush-stroke of possible changes in species' ranges, such methods harbour large uncertainties and are inadvisable as tools for protecting specific land parcels. The most robust and safest actions that can be taken with existing knowledge and tools involve creating landscapes that provide multiple options for species to adjust naturally to anthropogenic climate change. For many species, this translates into increasing protection for undeveloped lands, particularly adjacent to areas of high biodiversity, and into arresting or even reversing habitat degradation to both expand potential natural habitat and provide corridors for passive migration between natural habitats.

For Quino, a low-key approach to conservation in the near-term (next 10-15 years) is likely to be effective. An upward range shift has already been encouraged by adding protection to areas into which the butterfly is expanding on its own. However, projected distributions indicate that, even in the medium-term (next 40 years) Quino will likely lose all suitable climate space in the region of its current distribution. For long-term persistence of Quino, conservation managers will again need to consider assisted colonization. We expect that many species will benefit from adaptive management that embraces this type of steppingstone approach to conservation in a time of rapid climate change, where attention to real-time dynamics can reduce current uncertainty in model projections by informing managers as to which future (projected) pathway appears to be most appropriate for their species.

Acknowledgments We thank the United States Fish and Wildlife Service for compiling Quino records. Modeling was performed at Texas Advanced Computing Center (TACC). We are very grateful to John Fonner at TACC for training MM and for his cheerful help throughout. We also give many thanks to Seth McGinnis at NCAR for providing us with downscaled climate projection data and to Emilie Luciani for converting FWS GIS files for making lovely maps. We thank Dr. Richard Lowry for developing and maintaining the VassarStats website $<$ http://vassarstats.net $>$ that we used to perform the statistics presented in this paper. We also thank the PRISM Climate Group (Oregon State University, http://prism.oregonstate.edu) and the WorldClim Global Climate Data group (http://www.worldclim.org) for making their high resolution interpolated climate data freely available for research purposes. Personal observations by Paul Opler, Gordon Pratt, John Emmel and Ken Osborne were invaluable. We also thank two anonymous reviewers for their very helpful suggestions that have substantially improved the manuscript. The findings and conclusions in this article are those of the authors and do not necessarily represent the views of the U.S. Fish and Wildlife Service. Support came from the San Diego Foundation, the Okinawa Institute for Science and Technology (Japan) and from NSF Earth Systems Models Grant, Award Number 1049208.

\section{References}

Bennett NL, Severns PM, Parmesan C, Singer MC (2015) High resilience to climate change predicted in a butterfly with strong local adaptation. Oikos Early View online EV1-EV13. doi:10. 1111/oik.01490

Boggs CL, Holdren CE, Kulahci IG, Bonebrake TC, Inouye BD, Fay JP, McMillan A, Williams EH, Ehrlich PR (2006) Delayed population explosion of an introduced butterfly. J Anim Ecol 75:466-475

Bridle JR, Buckley J, Bodsworth EJ, Thomas CD (2014) Evolution on the move: specialization on widespread resources asssociated with rapid range expansion in response to climate change. Proc $\mathrm{R}$ Soc B 281:20131800

Buckley J, Bridle JR (2014) Loss of adaptive variation during evolutionary responses to climate change. Ecol Lett 17: $1316-1325$

Center for Biological Diversity (2010) Study: $60 \%$ of species recovery plans identify global warming as extinction threat but plans remain inconsistent, hindered by lack of federal guidance. http://www.biologicaldiversity.org/news/press_releases/2010/ recovery-plans-08-12-2010.html

Chen I-C, Hill JK, Ohlemüller R, Roy DB, Thomas CD (2011a) Rapid range shifts of species associated with high levels of climate warming. Science 333:1024-1026

Chen I-C, Hill JK, Shiu H-J, Holloway JD, Benedick S, Chey VK, Barlow HS, Thomas CD (2011b) Asymmetric boundary shifts of tropical montane lepidoptera over four decades of climate warming. Glob Ecol Biogeogr 20:34-45

Collins M, Knutti R, Arblaster J, Dufresne J-L, Fichefet $T$, Friedlingstein P, Gao X, Gutowski WJ, Johns T, Krinner G, Shongwe M, Tebaldi C, Weaver AJ, Wehner M (2013) Longterm climate change: projections, commitments and irreversibility, chap. 12. In: Stocker TF, Qin D, Plattner G-K, Tignor M, Allen SK, Boschung J, Nauels A, Xia Y, Bex V, Midgley PM (eds) Climate change 2013: the physical science basis. 
Contribution of working group I to the fifth assessment report of the intergovernmental panel on climate change. Cambridge University Press, Cambridge, UK, pp 1029-1136

Dawson TP, Jackson ST, House JI, Prentice IC, Mace GM (2011) Beyond predictions: biodiversity conservation in a changing climate. Science 332:53-58

DeVictor V, Van Swaay C, Brereton T, Brotons L, Chamberlain D, Heliölä J, Herrando S, Julliard R, Kuussaari M, Lindström A, Reif J, Roy DB, Schweiger O, Settele J, Stefanescu C, Van Strien A, Van Turnhout C, Vermouzek Z, WallisDeVries M, Wynhoff I, Jiguet F (2012) Differences in the climatic debts of birds and butterflies at a continental scale. Nat Clim Change 2:121-124

DiLuzio M, Johnson GL, Daly C, Eischeid JK, Arnold JG (2008) Constructing retrospective gridded daily precipitation and temperature datasets for the conterminous United States. J Appl Meteorol Climatol 47:475-497

Ehrlich PR, Murphy DD, Singer MC, Sherwood CB (1980) Extinction, reduction, stability and increase: the responses of checkerspot butterfly (Euphydryas) populations to the California drought. Oecologia 46:101-105

ESA (1973) US Endangered Species Act of 1973, as amended, Pub. L. No. 93-205, 87 Stat. 884. 28 December 1973. http://www.fws. gov/endangered/esa-library/pdf/ESAall.pdf

Evans DM, Che-Castaldo JP, Crouse D, Davis FW, Epanchin-Niell R, Flather CH, Frohlich RK, Goble DD, Li Y-W, Male TD, Master LL, Moskwik M, Neel MC, Noon BR, Parmesan C, Schwartz MW, Scott JM, Williams BK (in press) Species recovery in the United States: assessing the Endangered Species Act. Issues Ecol

Foden WB, Butchart SHM, Stuart SN, Vié J-C, Akçakaya HR, Angulo A, DeVantier LM, Gutsche A, Turak E, Cao L, Donner SD, Katariya V, Bernard R, Holland RA, Hughes AF, O'Hanlon SE, Garnett ST, Sekercioglu CH, Mace GM (2013) Identifying the world's most climate change vulnerable species: a systematic trait-based assessment of all birds, amphibians and corals. PLoS ONE 8(6):e65427. doi:10.1371/journal.pone.0065427

Forister ML, Shapiro AM (2003) Climatic trends and advancing spring flight of butterflies in lowland California. Glob Change Biol 9:1130-1135

Forister ML, McCall AC, Sanders NJ, Fordyce JA, Thorne JH, O'Brien J, Waetjen DP, Shapiro AM, Berenbaum MR (2010) Compounded effects of climate change and habitat alteration shift patterns of butterfly diversity. Proc Natl Acad Sci USA 107:2088-2092

Franco AMA, Hill JK, Kitsche C, Collingham YC, Roy DB, Fox R, Huntley B, Thomas CD (2006) Impacts of climate warming and habitat loss on extinctions at species' low-latitude range boundaries. Glob Change Biol 12:1545-1553

Gillson L, Dawson TP, Sam J, McGeoch MA (2013) (2013) Accommodating climate change contingencies in conservation strategy. Trends Ecol Evol 28:135

Glick P, Stein BA, Edelson NA (eds) (2011) Scanning the conservation horizon: a guide to climate change vulnerability assessment. National Wildlife Federation, Washington

Gomulkiewicz R, Shaw RG (2013) Evolutionary rescue beyond the models. Philos Trans R Soc B Sci 368(1610):20120093

Gonzalez A, Bell G (2013) Evolutionary rescue and adaptation to abrupt environmental change depends upon the history of stress. Philos Trans R Soc B Sci 368(1610):20120079

Hanski I, Singer MC (2001) Extinction-colonization dynamics and host-plant choice in butterfly metapopulations. Amer Natur 158:341-353

Hartmann DL, Klein Tank AMG, Rusticucci M, Alexander LV, Brönnimann S, Charabi Y, Dentener FJ, Dlugokencky EJ, Easterling DR, Kaplan A, Soden BJ, Thorne PW, Wild M, Zhai PM (2013) Observations: atmosphere and surface, chap. 2. In:
Stocker TF, Qin D, Plattner G-K, Tignor M, Allen SK, Boschung J, Nauels A, Xia Y, Bex V, Midgley PM (eds) Climate change 2013: the physical science basis. Contribution of working group I to the fifth assessment report of the intergovernmental panel on climate change. Cambridge University Press, Cambridge, pp 159-254

Heller NE, Zavaleta ES (2009) Biodiversity management in the face of climate change: a review of 22 years of recommendations. Biol Conserv 142:14-32

Hellmann JJ (2002) The effect of an environmental change on mobile butterfly larvae and the nutritional quality of their hosts. J Anim Ecol 71:925-936

Hijmans RJ, Cameron SE, Parra JL, Jones PG, Jarvis A (2005) Very high resolution interpolated climate surfaces for global land areas. Int J Climatol 25:1965-1978

Hill JK, Thomas CD, Fox R, Telfer MG, Willis SG, Asher J, Huntley B (2002) responses of butterflies to twentieth century climate warming: implications for future ranges. Proc R Soc Lond B 269:2163-2171

Hoegh-Guldberg O, Hughes L, McIntyre SL, Lindenmayer DB, Parmesan C, Possingham HP, Thomas CD (2008) Assisted colonization and rapid climate change. Science 321:345-346

Holdren CE, Ehrlich PR (1981) Long-range dispersal in checkerspot butterflies: transplant experiments with Euphydryas gillettii. Oecologia 50:125-129

Hughes TP, Rodrigues MJ, Bellwood DR, Ceccarelli D, HoeghGuldberg O, McCook LN, Moltschaniwskyj M, Pratchett S, Steneck RS, Willis B (2007) Phase shifts, herbivory, and the resilience of coral reefs to climate change. Curr Biol 17:360-365

IPCC (2014) Summary for policymakers. In: Climate change 2014: impacts, adaptation, and vulnerability. In: Field CB, Barros VR, Dokken DJ, Mach KJ, Mastrandrea, MD, Bilir TE, Chatterjee M, Ebi, KL, Estrada YO, Genova RC, Girma B, Kissel ES, Levy AN, MacCracken S, Mastrandrea PR, White LL (eds) Part A: global and sectoral aspects. Contribution of working group II to the fifth assessment report of the intergovernmental panel on climate change. Cambridge University Press, Cambridge, pp 1-32

Johnson CR, Banks SC, Barrett NS, Cazzasus F, Dunstan PK, Edgar GJ, Frusher SD, Gardner C, Haddon M, Helidoniotis F, Hill KL, Holbrook NJ, Hosie GW, Last PR, Ling SC, Melbourne-Thomas J, Miller K, Pecl GT, Richardson AJ, Ridgway KR, Rintoul SR, Ritz DA, Ross DJ, Sanderson JC, Shepherd S, Slotwinski A, Swadling KM, Taw N (2011) Climate change cascades: shifts in oceanography, species' ranges and marine community dynamics in eastern Tasmania. J Mar Exp Biol Ecol 400:17-32

Kirkpatrick M, Peischl S (2013) Evolutionary rescue by beneficial mutations in environments that change in space and time. Philos Trans R Soc B Sci 368(1610):20120082

Kirtman B, Power SB, Adedoyin JA, Boer GJ, Bojariu R, Camilloni I, Doblas-Reyes FJ, Fiore AM, Kimoto M, Meehl GA, Prather M, Sarr A, Schär C, Sutton R, van Oldenborgh GJ, Vecchi G, Wang HJ (2013) Near-term climate change: projections and predictability, chap. 11. In: Stocker TF, Qin D, Plattner G-K, Tignor M, Allen SK, Boschung J, Nauels A, Xia Y, Bex V, Midgley PM (eds) Climate change 2013: the physical science basis. Contribution of working group I to the fifth assessment report of the intergovernmental panel on climate change. Cambridge University Press, Cambridge, pp 953-1028

Konvicka M, Maradova M, Benes J, Fric Z, Kepka P (2003) Uphill shifts in distribution of butterflies in the Czech Republic: effects of changing climate detected on a regional scale. Glob Ecol Biogeogr 12:403-410

Lawler JJ (2009) Climate change adaptation strategies for resource management and conservation planning. Ann N Y Acad Sci 1162:79-98 
Ling SD, Johnson CR, Frusher SD, Ridgway KR (2009) Overfishing reduces resilience of kelp beds to climate-driven catastrophic phase shift. Proc Natl Acad Sci 106(52):22341-22345

Mastrandrea MD, Field CB, Stocker TF, Edenhofer O, Ebi KL, Frame DJ, Held H, Kriegler E, Mach KJ, Matschoss PR, Plattner G-K, Yohe GW, Zwiers FW (2010) Guidance note for lead authors of the IPCC fifth assessment report on consistent treatment of uncertainties. Intergovernmental panel on climate change (IPCC). http://www.ipcc.ch

Mawdsley JR, O'Malley R, Ojima DS (2009) A review of climatechange adaptation strategies for wildlife management and biodiversity conservation. Conserv Biol 23:1080-1089

McBride CS, Singer MC (2010) Field studies reveal strong postmating isolation between ecologidcally divergent butterfly populations. PLoS Biol 8(10):31000529. doi:10.1371/journal.pbio. 1000529

McCoy RC, Garud NR, Kelley JL, Boggs CL, Petrov DA (2014) Genomic inference accurately predicts the timing and severity of a recent bottleneck in a nonmodel insect population. Mol Ecol 23:136-150

McLaughlin JF, Hellmann JJ, Boggs CL, Ehrlich PR (2002) Climate change hastens population extinctions. Proc Natl Acad Sci 99:6070-6074

Mearns LO, Gutowski W, Jones R, Leung R, McGinnis S, Nunes A, Qian Y (2009) A regional climate change assessment program for North America. Eos Trans Am Geophys Union 90:311-312

Mikheyev AS, Vo T, Wee P-S, Singer MC, Parmesan C (2010) Rapid microsatellite isolation from a butterfly by de novo transcriptome sequencing: performance and a comparison with AFLP-derived distances. PLoS ONE 5:e11212

Mikheyev AS, McBride CS, Mueller UG, Parmesan C, Smee MR, Stefanescu C, Wee B, Singer MC (2013) Host-associated genomic differentiation in congeneric butterflies: now you see it, now you don't. Mol Ecol 22:4753-4766

Miller MP, Pratt GF, Mullins TD, Haig SM (2014) Comparisons of genetic diversity in captive versus wild populations of the federally endangered quino checkerspot butterfly (Euphydryas editha quino Behr; Lepidoptera, Nymphalidae). Proc Entomol Soc Wash 116:80-90

Parmesan C (1996) Climate and species range. Nature 382:765-766

Parmesan C (2003) Butterflies as bio-indicators of climate change impacts. In: Boggs CL, Watt WB, Ehrlich PR (eds) Evolution and ecology taking flight: butterflies as model systems. University of Chicago Press, Chicago, pp 541-560

Parmesan C (2005) Case study: Euphydryas editha. Special essay. In: Lovejoy T, Hannah L (eds) Climate change and biodiversity. Yale University Press, New Haven

Parmesan C (2006) Ecological and evolutionary responses to recent climate change. Annu Rev Ecol Syst 37:637-669

Parmesan C, Galbraith G (2004) Observed ecological impacts of climate change in North America. Pew Center on Global Climate Change, Arlington

Parmesan C, Yohe G (2003) Globally coherent fingerprints of climate change impacts across natural systems. Nature 421:37-42

Parmesan C, Ryrholm N, Stefanescu C, Hill JK, Thomas CD, Descimon H, Huntley B, Kaila L, Kullberg J, Tammaru T, Tennent J, Thomas JA, Warren M (1999) Poleward shift of butterfly species' ranges associated with regional warming. Nature 399:579-583

Parmesan C, Duarte CM, Poloczanska ES, Richardson AJ, Schoeman DS, Singer MC (2013) Beyond climate change attribution in ecology and conservation research. Ecol Lett Special Issue "The ecological effects of environmental change." 16(S1):58-71. doi:10.1111/ele.12098

Poloczanska ES, Brown CJ, Sydeman WJ, Kiessling W, Schoeman DS, Moore PJ, Brander K, Bruno JF, Buckley L, Burrows MT,
Duarte CM, Halpern BS, Holding J, Kappel CV, O’Connor MI, Pandolfi JM, Parmesan C, Schwing F, Thompson SA, Richardson AJ (2013) Global imprint of climate change on marine life. Nat Clim Change 3(10):919-925

Pratt GF, Pierce CL (2008) A new larval host plant, Collinsia concolor, for the endangered Quino checkerspot, Euphydryas editha quino. J Lepid Soc 64:36-37

Pratt G, Hein E, Krofta D (2001) Newly discovered populations and food plants extend the range of the endangered Quino checkerspot butterfly, Euphydryas editha quino (Nymphalidae) in southern California. J Lepid Soc 55:169-171

Preston KL, Rotenberry JT, Redak R, Allen MF (2008) Habitat shifts of endangered species under altered climate conditions: importance of biotic interactions. Glob Change Biol 14:2501-2515

Preston K, Redak RA, Allen MF, Rotenberry JT (2012) Changing distribution patterns of an endangered butterfly: linking local extinction patterns and variable habitat relationships. Biol Conserv 152:280-290

Richardson DM, Hellmann JJ, McLachlan JS, Sax DF, Schwartz MW, Gonzalez P, Brennan EJ, Camacho A, Root TL, Sala OE, Schneider SH, Ashe DM, Clark JR, Early R, Etterson JR, Fielder ED, Gill JL, Minteer BA, Polasky S, Safford HD, Thompson AR, Vellend M (2009) Multi-dimensional evaluation of managed relocation. Proc Natl Acad Sci 106:9721-9724

Root TL, Price JT, Hall KR, Schneider SH, Rosenzweig C, Pounds JA (2003) Fingerprints of global warming on wild animals and plants. Nature 421:57-60

Rosenzweig C, Karoly D, Vicarelli M, Neofotis P, Wu Q, Casassa G, Menzel A, Root TL, Estrella N, Seguin B, Tryjanowski P, Liu C, Rawlins S, Imeson A (2008) Attributing physical and biological impacts to anthropogenic climate change. Nature 453:353-358

Scalercio S, Bonacci T, Mazzei A, Pizzolotto R, Brandmayr P (2014) Better up, worse down: bidirectional consequences of three decades of climate change on a relict population of Erebia cassioides. J Insect Conserv 18:643-650

Schwartz MW, Hellmann JJ, Mclachlan JM, Sax DF, Borevitz JO, Brennan J, Camacho AE, Ceballos G, Clark JR, Doremus H, Early R, Etterson JR, Fielder D, Gill JL, Gonzalez P, Green N, Hannah L, Jamieson DW, Javeline D, Minteer BA, Odenbaugh J, Polasky S, Richardson DM, Root TL, Safford HD, Sala O, Schneider SH, Thompson AR, Williams JW, Vellend M, Vitt P, Zellmer S (2012) Managed relocation: integrating the scientific, regulatory, and ethical challenges. Bioscience 62(8):732-743

Singer MC (1971) Evolution of food-plant preference in the butterfly Euphydryas editha. Evolution 25:383-389

Singer MC (1972) Complex components of habitat suitability within a butterfly colony. Science 176:75-77

Singer MC, McBride CS (2010) Multitrait, host-associated divergence among sets of butterfly populations: implications for reproductive isolation and ecological speciation. Evolution 64(4):921-933

Singer MC, McBride CS (2012) Geographic mosaics of species' association: a definition and an example driven by plant-insect phenological synchrony. Ecology 93:2658-2673

Singer MC, Parmesan C (1993) Sources of variation in patterns of plant-insect association. Nature 361:251-253

Singer MC, Parmesan C (2010) Phenological asynchrony between herbivorous insects and their hosts: a naturally-evolved starting point for climate change impacts? Philos Trans R Soc Lond B 365:3161-3176

Singer MC, Ng D, Thomas CD (1988) Heritability of oviposition preference and its relationship to offspring performance within a single insect population. Evolution 42:977-985

Singer MC, Moore RA, Ng D (1991) Genetic variation in oviposition preference between butterfly populations. J Insect Behav $4: 531-535$ 
Singer MC, Vasco DA, Parmesan C, Thomas CD, Ng D (1992) Distinguishing between preference and motivation in food choice: an example from insect oviposition. Anim Behav 44:463-471

Singer MC, Thomas CD, Parmesan C (1993) Rapid human-induced evolution of insect diet. Nature 366:681-683

Thomas CD, Bodsworth EJ, Wilson RJ, Simmons AD, Davies ZG, Musche M, Conradt L (2001) Ecological and evolutionary processes at expanding range margins. Nature 411:577-581

Thomas CD, Hill JK, Anderson BJ, Bailey S, Beale CM, Bradbury RB, Bulman CR, Crick HQP, Eigenbrod F, Griffiths HM, Kunin WE, Oliver TH, Walmsley CA, Watts K, Worsfold NT, Yardley $\mathrm{T}$ (2011) A framework for assessing threats and benefits to species responding to climate change. Methods Ecol Evol $2: 125-142$

Thuiller W, Lafourcade B, Engler R, Araujo MB (2009) BIOMOD-a platform for ensemble forecasting of species distributions. Ecography 32:369-373

[USFWS] United States Fish and Wildlife Service (2003) Recovery plan for the Quino checkerspot butterfly (Euphydryas editha quino). Portland, Oregon, $\mathrm{x}+179 \mathrm{pp}$

[USFWS] United States Fish and Wildlife Service (2008) Endangered and threatened wildlife and plants; revised designation of critical habitat for the Quino checkerspot butterfly (Euphydryas editha quino); proposed rule. Fed Reg 73:3328-3373

[USFWS] United States Fish and Wildlife Service (2009a) Quino checkerspot butterfly (Euphydryas editha quino) 5-year review: summary and evaluation. U.S. Fish and Wildlife Service Carlsbad Fish and Wildlife Office Carlsbad, California

[USFWS] United States Fish and Wildlife Service (2009b) Endangered and threatened wildlife and plants; revised designation of critical habitat for the Quino checkerspot butterfly (Euphydryas editha quino); final rule. Fed Reg 74:28776-28862

Weiss SB, Murphy DD, White RR (1988) Sun, slope and butterflies: topographic determinants of habitat quality for Euphydryas editha. Ecology 69:1486-1496

Willis SG, Hill JK, Thomas CD, Roy DB, Fox R, Blakeley DS, Huntley B (2009) Assisted colonization in a changing climate: a test-study using two U.K. butterflies. Conserv Lett 2:45-51

Wilson RJ, Gutierrez D, Gutierrez J, Martinez D, Agudo R, Monserrat VJ (2005) Changes to the elevational limits and extent of species' ranges associated with climate change. Ecol Lett 8:1138-1146

Wilson RJ, Gutierrez D, Gutierrez J, Monserrat VJ (2007) An elevational shift in butterfly species richness and composition accompanying recent climate change. Glob Change Biol 13:1873-1887 